Alma Mater Studiorum - Università di Bologna DEPARTMENT OF ECONOMICS

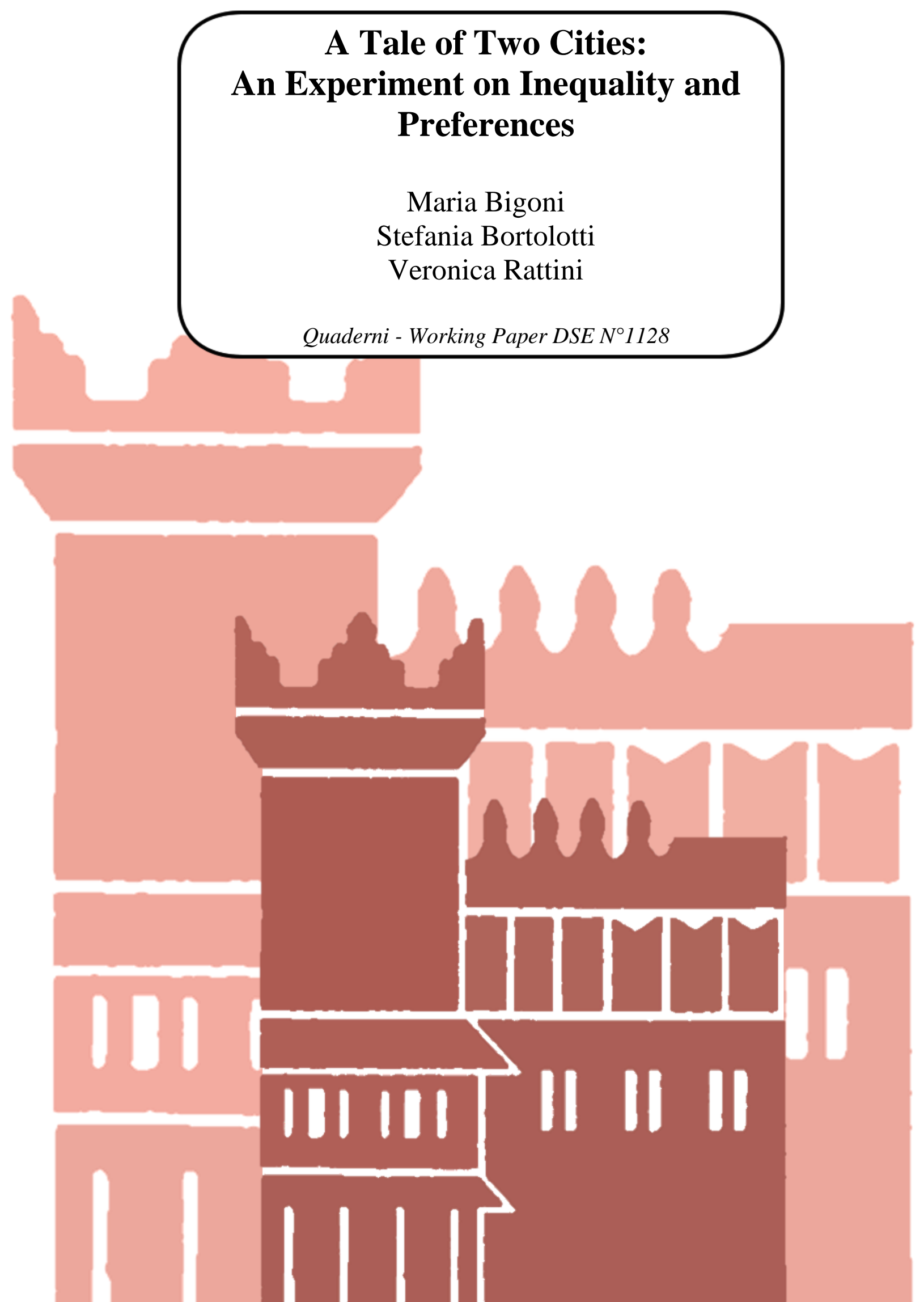




\title{
A Tale of Two Cities An Experiment on Inequality and Preferences ${ }^{\dagger}$
}

\author{
Maria Bigoni ${ }^{\ddagger}$ \\ University of Bologna \& IZA
}

\author{
Stefania Bortolotti \\ Max Planck Institute, Bonn
}

\author{
Veronica Rattini \\ University of Pittsburgh
}

\begin{abstract}
We study how differences in socio-economic background correlate with preferences and beliefs, in a sample of college students born in a mid-sized Italian city. Our findings indicate that participants living in an area characterized by a high socio-economic environment tend to trust more and are more inclined to reciprocate higher levels of trust, as compared to those coming from less wealthy neighborhoods. This behavioral difference is, at least in part, driven by heterogeneities in beliefs: subjects from the most affluent part of the city have more optimistic expectations on their counterpart's trustworthiness than those living in a lower socio-economic environment. By contrast, no significant differences emerge in other preferences: generosity, risk-attitudes, and time preferences. Finally, we do not find any systematic evidence of out-group discrimination based on neighborhood identity.
\end{abstract}

Keywords: Socio Economic Status, Beliefs, Generosity, Risk attitudes, Time preferences, Trust, Trustworthiness.

JEL classification: C90, D31, D63, R23.

\footnotetext{
${ }^{\dagger}$ We thank E. Fatas, R. Weber, D. B. Huffman for insightful discussions. We are grateful to participants at the IMEBESS Workshop in Florence and the NoBeC Workshop for useful comments. This work was supported by the Italian Ministry of Education and Research [SIR grant no. RBSI14I7C8]; and the UniCredit \& Universities Foundation [Modigliani Fellowship 2015]. The usual disclaimer applies.

${ }^{\ddagger}$ Corresponding author: Department of Economics, University of Bologna, Piazza Scaravilli 2, 40126 Bologna, Italy; maria.bigoni@unibo.it, Phone: +39 0512098134.
} 


\section{NON-TECHNICAL SUMMARY}

Inequality has been increasing steadily in industrialized societies and cities have grown divided, to the extent that household income inequality measured at the city level may be even larger than inequality at the country level.

Here we study how economic disparities between areas of the same metropolitan city correlate with residents' preferences. A link between socio-economic status (SES) and preferences has been documented in a few recent studies. Differences in preferences (e.g., risk attitudes, impatience, self-control, and social preferences) may have important economic consequences, since these traits have been shown to have a long-term effect on outcomes, such as ranging educational attainments, earnings, health, and criminal behavior.

Our study focuses on a pool of participants composed of well-educated young adults, who are currently enrolled in the university or have just completed their studies. Our subject pool is remarkably homogeneous in terms of education, ethnicity, and religion; it is also likely that our participants have been exposed to daily interactions with peers from different backgrounds for years. As a consequence, any difference in preferences and beliefs between participants from areas with different socio-economic background would be even more surprising and would provide evidence for the long-lasting effect of environmental conditions and early socialization.

In an online study, we exploit the existing differences in socio-economic status (SES) between residents of different areas of an Italian city. We elicit participants' trust, generosity, time and risk preferences by means of standard, incentive compatible procedures. Our main goal is to test if the preferences of participants from high and low SES areas display systematically different patterns.

We report three main results. First, participants from the High SES area trust more, are more trustworthy, and expect more trustworthiness than their peers from the Low SES area. No significant differences emerge in terms of generosity, risk attitudes and time preferences. Second, we find that most of the heterogeneity in trust behavior between the two areas is explained by beliefs about trustworthiness. Finally, we do not find any evidence of systematic out-group discrimination. 


\section{Introduction}

Inequality has been increasing steadily in industrialized societies over the last decades, and this has been recognized as one of the main societal challenges (OECD, 2011). Cities have grown divided, to the extent that household income inequality measured at the city level may be even larger than inequality at the country level. ${ }^{1}$ Thus, affluent and extremely poor districts often coexist next to one another, divided only by an invisible line.

Here we study how economic disparities between areas of the same metropolitan city correlate with residents' preferences in strategic and non-strategic situations. In an online study, we exploit the existing differences in socio-economic status (SES) between residents of different areas of an Italian city. We ask subjects to participate in a Trust Game and a Dictator Game, and we elicit their time and risk preferences by means of standard, incentive compatible procedures. Our main goal is to test if the preferences of participants from high and low SES areas display systematically different patterns.

In our study, the distinction between high and low SES is based on the area of residence of participants and not on their actual income (or the one of their household). This choice is meant to minimize any possible demand effect and is also informed by the recent empirical literature on neighborhoods effects, showing that childhood exposure to different environments has a long-term effect on earnings, college attendance, fertility, and marriage patterns (Chetty et al., 2016).

A link between socio-economic status (of the participant or of the family) and preferences has been documented in a few recent studies. In a survey conducted in Sweden respondents in the bottom half of the income distribution report a significantly lower level of generalized trust with respect to those at the top (Gustavsson and Jordahl, 2008); the correlation between wealth and generosity, instead, is still debated (Andreoni et al., 2017; Piff et al., 2010). A small but growing literature has documented that family socio-economic characteristics correlate with children's risk attitudes, impatience, self-control, and social preferences (Bauer et al., 2014; Castillo et al., 2011; Deckers et al., 2015; Delaney and Doyle, 2012; Kosse et al., 2018). Differences along these dimensions may have important economic consequences, since these traits have been shown to have a long-term effect on a wide variety of life outcomes, ranging from educational attainments and earnings, to health conditions, up to criminal behavior (Golsteyn et al., 2014; Mischel et al., 1989; Moffitt et al., 2011; Sutter et al., 2013).

\footnotetext{
${ }^{1}$ This is the case for some large US cities, such as New York or San Francisco. United States Census Bureau, 2005-2009. http://www.census.gov/prod/2011pubs/acs-16.pdf.
} 
A peculiarity of our experiment is that our subject pool is composed of well-educated young adults, who are currently enrolled in the university or have just completed their studies. Most of our participants still live with their family. This is a particularly appealing feature of our sample, as it excludes any possibility of self-selection into a given area. While the parents of our participants made a conscious choice in terms of housing - driven by income, preferences, convenience, etc. - it is safe to assume that their children had little or no saying in this decision. Our subject pool is remarkably homogeneous in terms of education, ethnicity, and religion; dimensions that could affect cooperative behavior and preferences in general (Chakravarty et al., 2016; Chuah et al., 2016; Fershtman and Gneezy, 2001; Koopmans and Veit, 2014; Weng and Yang, 2014). Since the majority of our sample is composed of college students, it is also likely that our participants have been exposed to daily interactions with peers from different backgrounds for years. As a consequence, any difference in preferences and beliefs between participants from areas with different SES would be even more surprising and would provide evidence for the long-lasting effect of environmental conditions and early socialization.

Furthermore, experimental economists are increasingly using laboratory experiments to measure the importance of the recipient's identity in cooperation and coordination games. ${ }^{2}$ Our study adds to this strand of the literature by additionally testing whether participants discriminate by conditioning their behavior on the socio-economic background of their counterpart in the Trust and Dictator Game.

To this aim, we build on the design developed by Falk and Zehnder (2013), who ran a large experiment involving a random sample of the adult residents of Zurich, and found evidence that trustors condition their behavior on the trustee's district of residence. ${ }^{3}$ In both the Trust and the Dictator Game, we provide participants with information on their counterpart's area of residence (which may be perceived as a signal of socio-economic status). The final goal is to verify if participants from low SES areas are less likely to show preferences and beliefs that are conducive to cooperation - in general or specifically when they face counterparts from wealthy neighborhoods - hence potentially missing opportunities for their development and bolstering

\footnotetext{
${ }^{2}$ For a meta-analysis on discrimination in laboratory experiment see Lane (2016).

${ }^{3}$ Our paper also relates to McEvily et al. (2012) who study how both behavioral and attitudinal measures of trust varies with the target of trust. We instead focus on how trust, trustworthiness and generosity vary with the individual characteristics of both the first and second movers. We recently became aware that a similar approach has been adopted by Blanco and Guerra (2017) in an experiment conducted in Bogota (Colombia), with college students from different socio-economic status.
} 
poverty and social fragmentation.

We report three main results. First, participants from the High SES area trust more, are more trustworthy, and expect more trustworthiness than their peers from the Low SES area. No significant differences emerge in decision tasks that do not imply any strategic interaction, through which we measure generosity, risk attitudes and time preferences. Second, we find that most of the heterogeneity in trust behavior between the two areas is explained by beliefs about trustworthiness. We also find support for the consensus effect in explaining the belief formation process. Finally, we do not find any evidence of systematic out-group discrimination. Participants do not change their behavior in the Trust and Dictator Game if they are matched with someone from their same area of residence or a different one.

The paper is structured as follows. Section 2 describes the experimental location, the subject pool, and the design of the online experiment. Section 3 reports the main results of the paper and Section 4 concludes.

\section{Experimental design}

In this section, we start by describing the location where the experiment took place, and the subject pool. We then detail the experimental design and the procedures.

\subsection{Location and subject pool}

All participants in the study were born in the metropolitan area of Bologna, a medium-size city located in the North of Italy. The municipality of Bologna has a population of about 380,000 inhabitants, while the metropolitan area includes about 1 million inhabitants. At the time when the experiment was run, the municipality was divided into nine districts (Figure 1).

While no formal borders are present within the municipality, a clear socio-economic division exists between the Northern and Southern areas (see Table 1 and Figure 1). The divide emerges along many important dimensions. First and foremost, the average income is $25 \%$ lower in the North as compared to the South area. This is a quite sizable difference especially if one considers that Bologna is a medium-size municipality. Another important dimension to asses the socioeconomic environment is the education level. The incidence of residents with at least a bachelor degree goes from $43 \%$ in the North area to $61 \%$ in the South area. Moreover, the Northern most area is characterized by a higher degree of multiculturalism and by a relatively lower 
Figure 1: Income distribution in Bologna

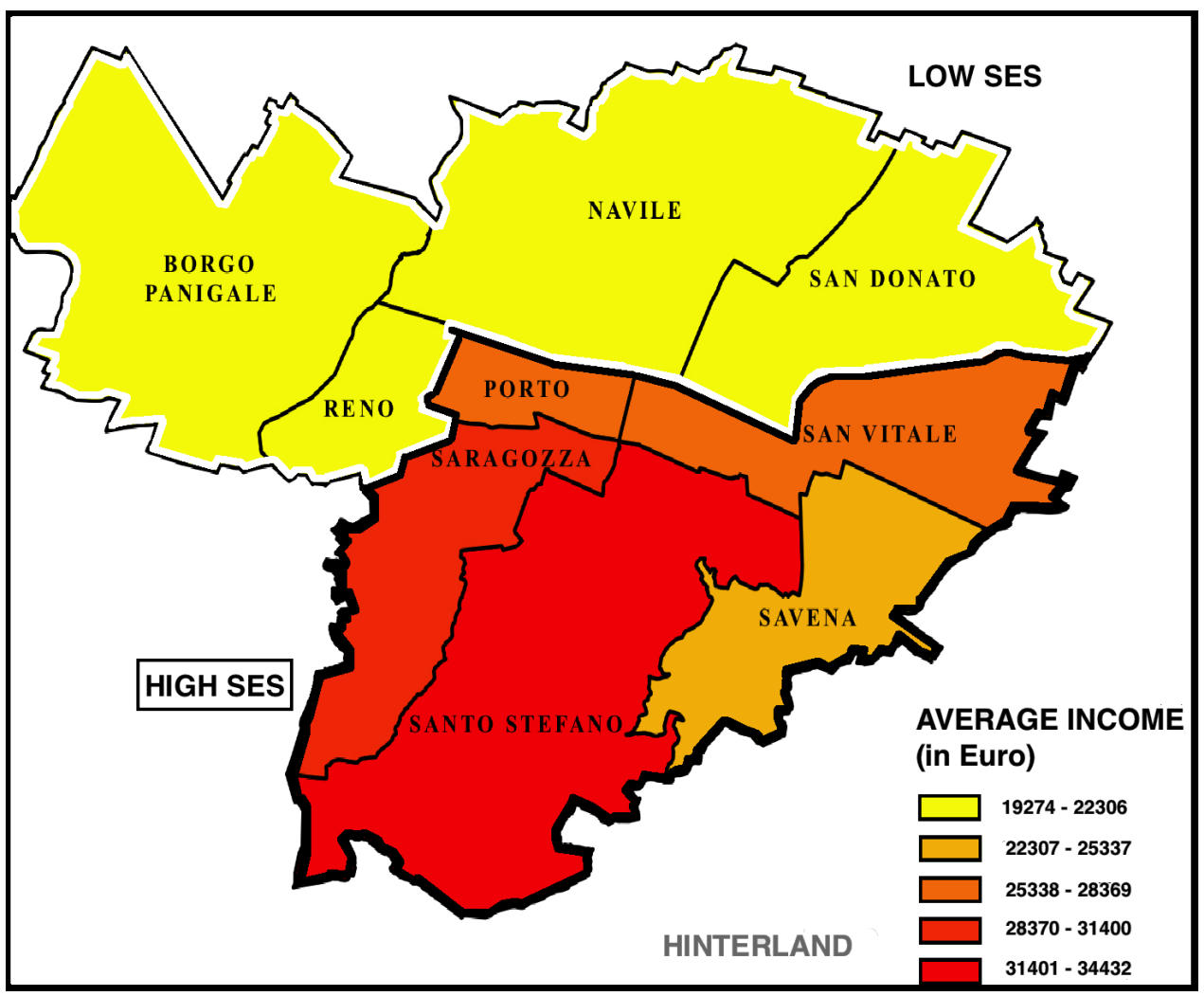

Notes: The Low SES area (North) includes: Borgo Panigale, Navile, San Donato, and Reno. The High SES area (South) includes: Porto, San Vitale, Savena, Saragozza, and Santo Stefano. The heat map shows the average income for the year 2014 expressed in Euro (source: Statistical Office of the Municipality of Bologna).

political participation (measured by the turnout in the 2016 national constitutional referendum). The latter difference emerges even in the local municipal elections (Bellettini et al., 2016). ${ }^{4}$ Throughout the paper, we will refer to the North area as the Low SES area and to the South area as the High SES one.

The division between the two areas reflects a rooted sentiment among the local population. Especially among teenagers and adolescents, rather unflattering nicknames for the two areas are commonly used. While the level of social tension is fairly low, it is important to stress that the

\footnotetext{
${ }^{4}$ Bellettini et al. (2016) show that districts characterized by lower income, higher inequality, and higher percentages of foreign residents have a lower turnout rate than wealthier and more homogeneous neighborhoods, in the 2004 and 2009 local elections in Bologna. As the authors suggest, this difference is in line with the idea that higher contextual heterogeneity could discourage electoral turnout since it might reduce civic cohesion and engagement.
} 
Table 1: Socio-economic characteristics of the districts

\begin{tabular}{lcccc}
\hline \hline & $\begin{array}{c}\text { Income } \\
(\text { in } € \text { ) }\end{array}$ & $\begin{array}{c}\text { Foreigners } \\
(\%)\end{array}$ & $\begin{array}{c}\text { Bachelor } \\
\text { or more (\%) }\end{array}$ & $\begin{array}{c}\text { Referenda } \\
\text { Turnout (\%) }\end{array}$ \\
\hline Low SES (North) & 20,928 & 17 & 43 & 75 \\
Borgo Panigale & 21,143 & 15 & 41 & 76 \\
Navile & 20,924 & 20 & 46 & 75 \\
San Donato & 19,804 & 18 & 43 & 73 \\
Reno & 21,843 & 15 & 45 & 76 \\
High SES (South) & 28,366 & 12 & 61 & 77 \\
& & & & \\
Porto & 26,439 & 13 & 62 & 76 \\
San Vitale & 26,133 & 14 & 60 & 77 \\
Savena & 23,887 & 13 & 51 & 77 \\
Saragozza & 30,061 & 11 & 65 & 77 \\
Santo Stefano & 35,312 & 10 & 68 & 77 \\
Hinterland & 20,706 & 11 & 41 & \\
\hline
\end{tabular}

Notes: The data are provided by the Statistical Office of the Municipality of Bologna. Income is the average income in 2014. Foreigners is the percentage of foreigners over the residing population in 2011 (last available census). Bachelor or more is the fraction of the population with a bachelor degree or a higher education level. Turnout is the turnout rate in the 2016 national referendum.

division and the boundaries of the two areas are commonly perceived and understood by the local population. ${ }^{5}$

The subject pool. We recruited participants born in the metropolitan area of Bologna via ORSEE (Greiner, 2015). We were able to screen subjects on the basis of the information available in our database, so no reference to the subjects' origins was made in the recruitment message.

Table A1 shows that about one-third of participants live in the hinterland, outside the municipality of Bologna. The hinterland of the metropolitan area of Bologna is quite

\footnotetext{
${ }^{5}$ The High SES area is often called the "Bolobene" (that could loosely translate into well off Bologna) and the Low SES area is sometimes dubbed "Bolofeccia" (the dregs of Bologna). No major incidents or fights between the two factions have occurred in the past. The main exception is a fight between two large groups from the two areas involving about 200 adolescents in the summer of 2013. https://www.ilrestodelcarlino.it/bologna/ cronaca/2013/09/14/949754-rissa-ricchi-poveri-ask.shtml
} 
heterogeneous. The average income ranges between $19,386 €$ and $28,111 €^{6}$ and the fraction of foreigners over the total population ranges between $5.6 \%$ and $15.2 \%{ }^{7}$ We decided not to exclude these subjects from our sample, because on the one hand their presence makes the purpose of the experiment less transparent, and on the other hand they represent an interesting benchmark for comparison.

A few considerations are in order. First, participants from the three areas - Low SES, High SES, and Hinterland - do not differ in terms of age, gender, and education level (Table A1 in the Appendix). This is not surprising since we mostly draw from the student population of the University of Bologna.

Second, we have information about the place of residence at the time of birth; only a quarter of our subject pool moved across areas. Of those who moved, $40 \%$ are born in the Hinterland and moved to the High SES area, while $20 \%$ moved in the opposite direction; only a minority moved from the Low to the High SES (14\%) or viceversa (14\%). The lowest level of mobility is observed among participants living in the Low SES area. A substantial portion of our participants (77\%) still live with their parents, and the figures are similar across areas. ${ }^{8}$ We also have information about the area where their best friend lives. One third of the participants from the Low SES have a best friend living in the High SES, while this number increases to $45 \%$ for participants from High SES. This evidence can be understood as an additional sign that our subject pool is quite homogeneous and socialized.

\subsection{Experimental design}

The experiment consists of four games presented in a fixed order: (i) Trust Game; (ii) Dictator Game; (iii) time preferences task; and (iv) risk preferences task. Below we describe in detail how we implemented each of these games.

Trust Game. To capture trust and trustworthiness, we used a variation of the Trust Game developed by Berg et al. (1995). Participants were divided into pairs comprising one trustor and one trustee. Trustors were endowed with $5 €$ that had to be divided between themselves and the

\footnotetext{
${ }^{6}$ Source: http://statistica.comune.bologna.it/atlantemetropolitano/economia/reddito-medioclassi-e-tipologie-di-reddito, year 2015.

${ }^{7}$ Source: http://statistica.comune.bologna.it/atlantemetropolitano/popolazione/stranieri/ stranieri-sesso-e-et, year 2016.

${ }^{8}$ This is not uncommon in Italy; students going to college in the city where they were born and where their family resides, usually live with their parents.
} 
trustee. Any amount sent to the trustee was tripled, and the trustees could decide how much of the tripled amount to keep for themselves and how much to return to the trustor. A selfinterested rational player should send back nothing while playing as a trustee and, by backward induction, a trustor should keep the entire endowment. However, efficiency is maximized when the trustor sends the entire endowment to the trustee.

The amount sent by the trustor to the trustee is commonly understood as a proxy for trust, while the amount sent back by the trustee is a proxy for trustworthiness. We used the role reversal and the strategy method. That means that all players played in both roles - first as trustors and then as trustees. Moreover, while deciding as trustees, they had to make a decision for each possible amount sent by the trustor. To avoid any carry-over effect, roles were assigned, and feedback were provided only at the end of the experiment. After making their decisions as trustor and trustee, subjects were also asked to state their beliefs about the trustworthiness level of their counterpart. We asked what percentage of the tripled amount they expected back from the trustee, in intervals of 10 percentage points. ${ }^{9}$

Dictator Game. To measure the generosity level of our subjects, we used the Dictator Game (Kahneman et al., 1986). Participants were divided into pairs comprising one dictator and one recipient. We informed subjects that the opponent for this game was not the same as the one in the Trust Game. Dictators were endowed with $10 €$ and had to decide how much to keep for themselves and how much to give to the recipient, who had no decision to make. A self-interested dictator should keep the entire endowment, while positive transfers are interpreted as a proxy for generosity. Here, as in the Trust Game, we used the role-reversal; all players were asked to make a decision as dictators. Roles were assigned and revealed at the end of the experiment.

Time preferences. After the Dictator Game, we elicited time preferences through a Multiple Price List. Each subject had to make 10 choices between two options. Option A paid $100 €$ one week after the end of the experiment, while Option B paid a larger amount one week and three months after the end of the experiment. While the amount paid by Option A was the same in all decisions, the amount paid by Option B increased in steps of $3 €$ from one decision to the other and ranged from $103 €$ (decision 1) to $130 €$ (decision 10, see the Instructions in the Appendix). The switching point from Option A to Option B is our proxy for time preferences.

\footnotetext{
${ }^{9}$ In the experiment, this question was not incentivized. While there is not clear cut evidence that payment increases accuracy (see for example Costa-Gomes and Weizsäcker, 2008), previous studies have found that incentivizing beliefs may induce a change in behavior (Gächter and Renner, 2010).
} 
The later the subjects switch from A to B, the more impatient they are. 7 participants ( 1 in 20) were randomly selected for payment for this part, and the relevant decision was also drawn at random by the computer. Payments for this task were carried out via bank transfer on the selected date.

Risk preferences. Finally, we elicited risk preferences by means of the "Bomb Risk Elicitation Task" developed by Crosetto and Filippin (2013). Subjects were presented with a $5 \times 5$ table containing 25 cells. Every 2 seconds a cell was automatically activated and colored in red. The earnings increased linearly with the number of activated cells; more precisely, any activated cell yielded 50 cents. However, behind one of the 25 cells there was a "bomb"; if that cell was activated all the earnings for this task vanished. Subjects had to decide when to stop activating new cells. The position of the "bomb" was revealed only at the end of the experiment. In this task, subjects faced a trade-off between the amount of money they could make and the risk of activating the cell containing the "bomb". The number of cells activated by a subject is negatively correlated with his or her degree of risk aversion.

Treatments. We had three between-subjects treatments in which we varied the area of residence of the opponent - Low SES, High SES, or Hinterland. ${ }^{10}$ The treatments applied only to the first two games - Trust Game and Dictator Game - where another player was involved.

At the beginning of the experiment, before playing the Trust Game, all subjects were asked to answer a short questionnaire where they also had to report the district where they were living at the time of the experiment. To facilitate the task, we also showed a map of the boundaries of the districts (see the Instructions in the Appendix). In the Trust Game and in the Dictator Game, subjects were told that their counterpart was participating in the same study and was from one of the three areas.

To limit any possible demand effect, we did not make any reference to the SES characteristics of the areas, but simply displayed a map with the three areas highlighted in different colors (Figure A1 in the Appendix). The blue color identified the Low SES area, the green color indicated the High SES area, and the yellow one identified the Hinterland. The area of the counterpart was kept constant across the games, but the counterpart changed from the first to the second game (and this information was explicitly provided to subjects in the instructions).

\footnotetext{
${ }^{10}$ Here, we depart from Falk and Zehnder (2013) who varied the area of the opponent in a within-subjects fashion.
} 
Experimental procedures. The experiment was conducted in May 2016 online using the oTree software (Chen et al., 2016) and subjects were recruited via ORSEE (Greiner, 2015). In particular, we restricted the ORSEE subject pool to include only individuals born in the municipality of Bologna. We invited via email all the 296 participants fulfilling the requirement. Subjects were informed that the study itself was online and that they would have to collect their payment at the Bologna Laboratory for Experiments in Social Sciences (BLESS). They could choose from several dates and times to collect the payment and this decision had to be made before starting the study. We also made clear that the participation required to use a PC, a tablet or a smartphone and could be carried out from home or any other place with an internet connection. Moreover, we informed the potential participants that the typical payments ranged from $0 €$ to $30 €$, and the completion time was at most 30 minutes.

Figure 2: Timeline of the experiment

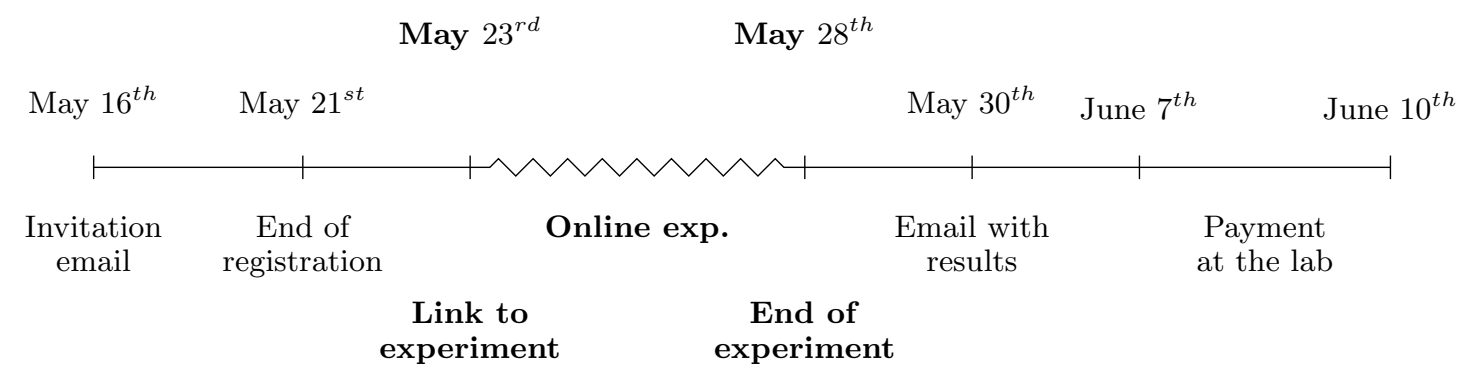

Figure 2 illustrates the timeline of the experiment. After registering for the experiment, subjects received a link to access the online experiment and had one week to complete the study in all its parts. Subjects could interrupt and go back to the experiment as many times as they wished. At the end of the week, all participants who successfully completed the experiment received an email with their earnings and a code to claim their payment. In total 153 subjects registered for taking part in the study, 145 started the study, and 144 completed it.

After reading the instructions for each part, subjects had to answer few control questions and could not proceed to the game until they answered all questions correctly. When giving a wrong answer, subjects were provided with some explanation and were required to answer the question again. After having completed the four games, subjects were asked to answer a questionnaire (see the Instructions in the Appendix). No feedback was provided during the experiment: participants received information about the results of each game and earnings via e-mail, at the end of the experiment. Earnings corresponded to the sum of the earnings in all 
tasks, with the only exception of time preferences for which only one out of every 20 participants was randomly selected for payment. The average payment was of $17.60 €$, and payments ranged from $2 €$ to $138 €$. Subjects collected their cash payments in a sealed envelope at the BLESS laboratory the date they had selected at the beginning of the study. ${ }^{11}$

\section{Results}

In this section, we first consider if there is any form of out-group discrimination. We want to test if participants trust more, are more trustworthy, and are more generous when matched with someone from their own area rather than from a different area of residence. We then test if participants living in a High SES area display different preferences compared to the ones from a Low SES area. We will focus on situations both with and without strategic interaction. Finally, we study the link between trust, trustworthiness, and beliefs to grasp a better understanding of the origins of the observed differences.

When we talk about High SES and Low SES, we refer to the area where the subject was living at the time of the experiment. We have information also about the area of residence at the time the participant was born, and we will use this information to check the robustness of our findings by adding a control for those subjects who moved to a different area. As a further control, we run additional robustness by restricting the sample to those participants whose areas of residence at the time of the experiment was the same as the one at the time of birth (stayers hereafter).

In the analysis, we consider the following behavioral measures:

- Trust: is defined as the share of the endowment sent to the trustee in the Trust Game;

- Trustworthiness: we adopt the measure of "reciprocal inclination" proposed by Falk and Zehnder (2013), which is obtained by estimating individual-level OLS regressions where the dependent variable is the amount sent back and the only regressor is the level of trust. As in Falk and Zehnder (2013), we set the intercept to zero to properly capture trustees' sensitivity to different levels of trust;

- Beliefs about trustworthiness are measured by the expected amount returned, as a fraction of the total sum received by the trustee;

\footnotetext{
${ }^{11}$ Earnings for time preferences were paid via bank transfers on the relevant day.
} 
- Generosity: is the share of the endowment sent to the recipient in the Dictator Game;

- Risk attitude: is the share of activated cells in the Bomb Risk Elicitation Task - larger shares are associated to stronger willingness to take risk;

- Impatience: is based on the number of the row, in the Multiple Price List, at which the individual switches from having $100 €$ today to having a higher amount in the future. The measure goes from 0 (if the respondent always chose the late amount) to 1 (if the respondent always chose the early amount): the higher the number, the higher the impatience level. ${ }^{12}$

\subsection{Out-group discrimination across areas}

In this section, we test if our participants behave differently when they are matched with someone from their own area of residence or from a different one. We focus on the behavior in the Dictator Game and in the Trust Game - as the other tasks did not involve a counterpart. We do not find any systematic evidence of out-group discrimination. Both in the Trust Game and in the Dictator Game, the behavior and beliefs of subjects who were matched with counterparts residing in their own area were not significantly different from those exhibited by subjects matched with someone from a different area (Table A2 and Figure A2 in the Appendix). On average, subjects showed a tendency to reciprocate slightly more towards out-group than ingroup members, but this was not true for residents in the Low SES area (Figure A2).

Result 1. We do not find any systematic evidence of out-group discrimination neither in the Trust Game nor in the Dictator Game.

The absence of any significant in-group bias, based on the area of residence of the counterpart, is consistent with the evidence by Blanco and Guerra (2017), who relied on a sample of college students in Colombia. The result is instead at odd with the findings reported by Falk and Zehnder (2013) for a representative sample of the general population. This is not necessarily surprising as we rely on a very different subject pool. Our sample is mostly composed of students who volunteer for experiments and the sense of belonging to the same community might overshade the differences along other dimensions, such as the area of residency.

\footnotetext{
${ }^{12}$ In the computation of this measure we drop 4 observations - 2 from the South and 2 from the Hinterland because these individuals switched multiple times.
} 


\subsection{SES of the area of residency and preferences}

Since we did not find any evidence of out-group discrimination, we pool all the data to study if any systematic difference in preferences emerges, depending on the subject's area of residence. That is, we want to test if participants from a high SES area display preferences and beliefs that are different from those exhibited by participants from a low SES area.

Figure 3: Heat maps of preferences and beliefs by SES area

(a) Situations with strategic interaction
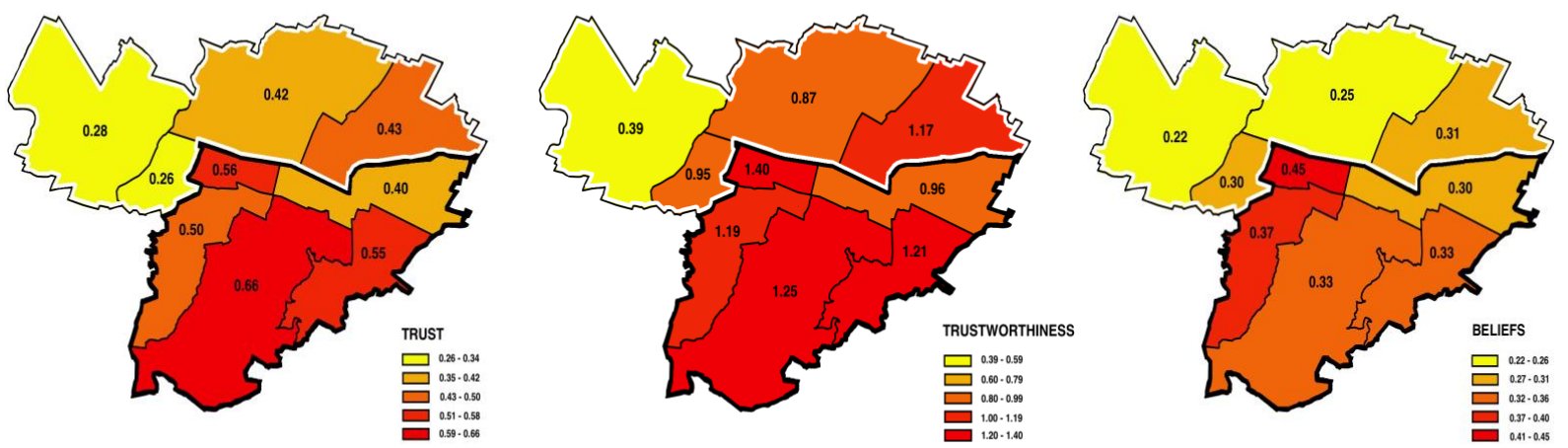

(b) Situations without strategic interaction
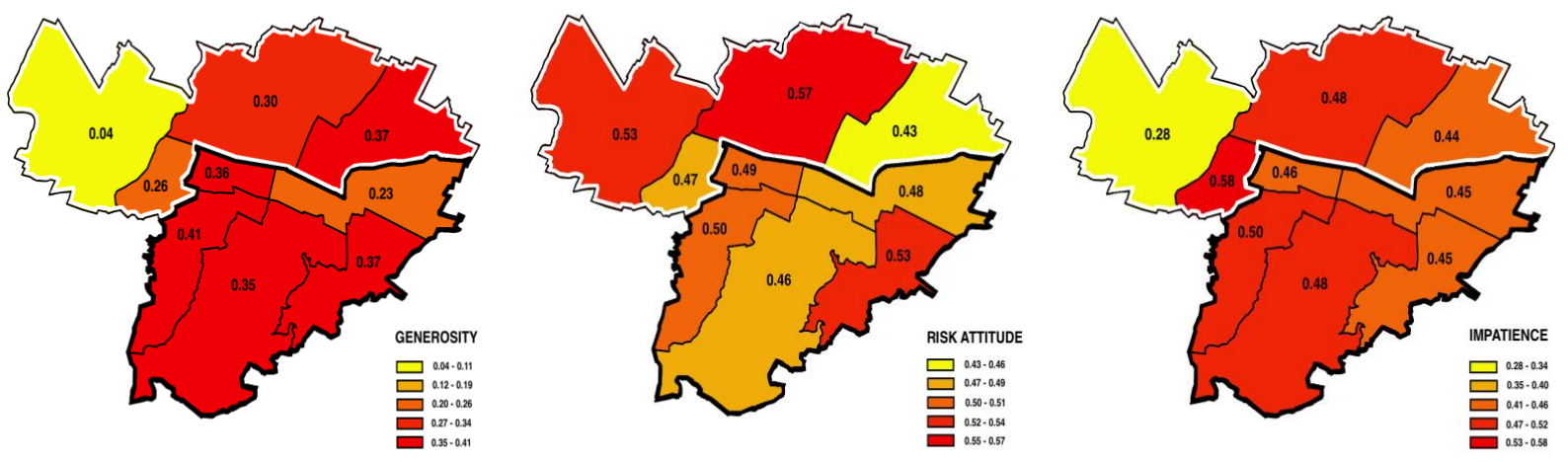

Situations with strategic interaction. Figure 3(a) reports the heat maps for trust, trustworthiness, and beliefs about trustworthiness by neighborhood. It is immediate to see that there is more trust in the High than in the Low SES area. A similar pattern is observed for trustworthiness and beliefs.

Table 2 reports the mean value of these three variables by area and summarizes results from non-parametric tests on the distributions. The data confirm that the difference in trust, 
trustworthiness, and beliefs between the Low and the High SES areas are significant (at least at the $10 \%$ level) along all three dimensions.

Table 2: Descriptive statistics by SES area

\begin{tabular}{lcccccc}
\hline \hline & Hinterland & Low SES & & High SES & & Hinterland \\
\hline \multicolumn{2}{l}{ Situations with } \\
Trust & 0.47 & $\sim 0.38$ & $<^{*}$ & 0.51 & $\sim$ & 0.47 \\
Trustworthiness & 1.03 & $\sim 0.91$ & $<^{* * *}$ & 1.15 & $\sim$ & 1.03 \\
Beliefs & 0.33 & $\sim 0.28$ & $<^{*}$ & 0.34 & $\sim$ & 0.33 \\
Situations without & strategic interaction & & & & \\
Generosity & $0.34 \quad \sim 0.28$ & $\sim$ & 0.33 & $\sim$ & 0.34 \\
Risk attitude & 0.51 & $\sim 0.51$ & $\sim$ & 0.50 & $\sim$ & 0.51 \\
Impatience & 0.36 & $\sim 0.46$ & $\sim$ & 0.47 & $\sim$ & 0.36 \\
\hline
\end{tabular}

Notes: Mean values by area and results from Wilcoxon rank-sum tests, with $N_{\text {High }}=64$ and $N_{\text {Low }}=$ 37. Symbols ${ }^{* * *},{ }^{* *}$, and ${ }^{*}$ indicate significance at the $1 \%, 5 \%$ and $10 \%$ level, respectively; $\sim$ indicates no significant differences.

This result is confirmed using formal regression analysis. Models 1 to 3 in Table 3 provide evidence in support of the correlation between SES and behavior and beliefs in the Trust Game. Model 1 reports Ordered Logit estimates for trust. The main regressors of interest are High SES, which takes value 1 if the decision maker is resident in the High SES area and 0 otherwise, and Hinterland that takes value 1 if the decision maker is resident in the area outside the municipality and 0 otherwise. We also include a dummy for the area of residency of the counterpart (as before, the baseline category is Low SES, and we include dummies for High SES and Hinterland). Finally, we control for a number of socio-demographic characteristics and answers to survey questions (see notes to Table 3 for further details). The regression analysis suggests that residents of the High SES area trust significantly more than the ones from a Low SES area. It is also interesting to notice that none of the dummies for the area of residency of the counterpart is significant. This suggests that not only we fail to observe any out-group discrimination, but none of the areas is discriminated against. To account for the censored nature of our data for trustworthiness (Model 2) and beliefs about trustworthiness (Model 3) we run Tobit regression. We replicate the same analysis as in Model 1 and obtain similar results also for these variables. ${ }^{13}$ So far we have considered all participants and have controlled for those who moved from one area to the other. As a further

\footnotetext{
${ }^{13}$ Results are robust when using a OLS specification instead of non-linear modelsand when we restrict the sample to those participants who reported to live in the same area where they were born (available upon request to the authors).
} 
robustness check, we have replicated Table 3 by restricting the sample to those participants who reported to live in the same area where they were born (i.e., stayers). Results for trust and trustworthiness are confirmed also for the subsample of stayers. We instead fail to find a significant effect of High SES for beliefs, but the direction of the effect is confirmed.

Table 3: Regressions on SES areas and preferences (situations with strategic interaction)

\begin{tabular}{lccc}
\hline \hline & Trust & Trustworthiness & Beliefs \\
& Model 1 & Model 2 & Model 3 \\
\hline Area of residence of the decision maker & & & \\
High SES (d) & $0.731^{* *}$ & $0.251^{* *}$ & $0.064^{*}$ \\
& $(0.373)$ & $(0.123)$ & $(0.036)$ \\
Hinterland (d) & 0.659 & 0.129 & 0.055 \\
& $(0.402)$ & $(0.133)$ & $(0.039)$ \\
Area of residence of the counterpart & & & \\
Opponent from High SES (d) & -0.090 & -0.053 & -0.004 \\
& $(0.357)$ & $(0.121)$ & $(0.035)$ \\
Opponent Hinterland (d) & 0.150 & 0.044 & -0.017 \\
& $(0.377)$ & $(0.124)$ & $(0.036)$ \\
Constant & & $0.624^{* *}$ & $0.348^{* * *}$ \\
& & $(0.371)$ & $(0.107)$ \\
\hline Controls & Yes & Yes & Yes \\
F-test High SES $=$ Hinterland & 0.709 & 0.182 & 0.600 \\
F-test Opp. from High SES $=$ Opp. from Hint. & 0.463 & 0.346 & 0.733 \\
N.obs. & 144 & 144 & 144 \\
$R^{2}$ & 0.020 & 0.055 & -0.147 \\
\hline
\end{tabular}

Notes: Model 1: Ordered Logit regression. Model 2-3: Tobit regressions. Symbols ${ }^{* * *},{ }^{* *}$, and * indicate significance at the $1 \%, 5 \%$ and $10 \%$ level, respectively. Dummy variables are indicated by the letter $d$. Controls include the following variables: Age of the participant in years; the dummy Female takes value 1 for females and 0 for males; the dummy Student takes value 1 if the participant is a student; the dummy Moved takes value 1 if a participant was born in an area different from the one he/she was living at the time of the experiment.

Figure 4 sheds further light on the difference across areas in terms of trustworthiness, showing that it mainly comes from the fact that the residents in the High-SES area tend to reciprocate more higher levels of trust.

Result 2. Participants from the High SES area trust more, are more trustworthy, and expect their counterpart to be more trustworthy as compared to participants from the Low SES area. 
Figure 4: Trustworthiness by SES area

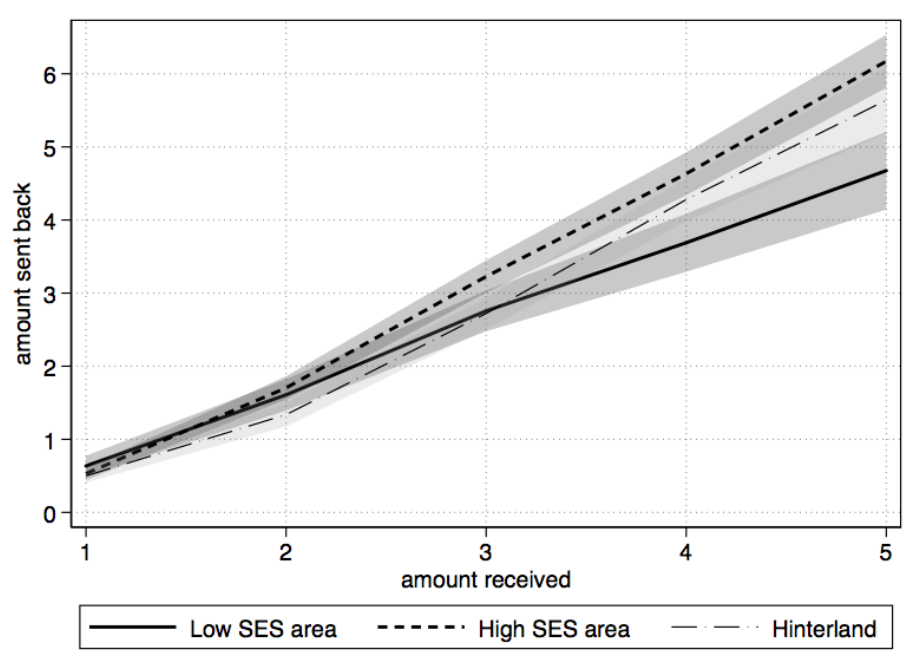

Situations without strategic interaction. We now consider behavior in the Dictator Game, risk aversion and time preferences. Figure 3(b) reports the heat maps for generosity, risk, and impatience, and Table 2 reports the mean values of these variables by area. No clear pattern emerges along these dimensions; while there is some variation across neighborhoods, it does not follow the High-Low SES division.

More specifically, we fail to find any significant difference between High and Low SES areas for generosity level, risk attitude, and patience. Support for these results is provided in Table ?? of the Appendix. ${ }^{14}$

Result 3. In dimensions that do not involve strategic interaction - generosity, risk attitudes and time preferences - we fail to find significant differences between the preferences of participants from High and Low SES areas.

\subsection{The Determinants of Trust}

From the previous analysis we have seen that, even if players do not change their actions based on their counterpart's area of residence, a significant difference emerges in the trust attitudes

\footnotetext{
${ }^{14}$ As a robustness check we run a series of OLS regressions and all the results are qualitatively and quantitatively the same. The results are confirmed also by a series of Tobit regressions on the sub-sample of the stayers.
} 
between residents living in Low and High SES areas. In this section, we try to measure what are the factors explaining this difference.

Trust. Previous research has shown that several factors can drive the trustor's behavior in the Trust Game: individual beliefs about trustworthiness (Gambetta, 1988), other-regarding and efficiency concerns (Ashraf et al., 2006; Cox, 2004) or individual risk preferences (Schechter, 2007). We follow the approach proposed by Sapienza et al. (2013) to better understand what explains the difference in trust levels between residents living in High and Low SES areas. To do so, we have to tease apart the two main drivers of trust: beliefs in others' trustworthiness and individual preferences (generosity, political and social preferences, and risk preferences).

In Model 1 of Table 3, we show that High SES areas are characterized by higher levels of trust. We now build on that model and try to understand if this tendency is driven by beliefs, preferences, and orientations. We proceed by adding to the baseline regression (Model 1, Table 3) preferences and beliefs as measured in the experiment, as well as measures taken from the questionnaire.

In Model 1 of Table 4, we expand the baseline estimation by adding controls that capture elicited preferences - risk attitude, time preferences and generosity - and beliefs on opponent's trustworthiness. We find that the most important component in explaining trust are the beliefs. As we have seen in the previous section, the beliefs are correlated with the area of residence of the individual; this explains why when we include this variable into the model, it captures all the impact of the High SES variable. Moreover, notice that our elicited measure of generosity is also a relevant factor in explaining the trust decisions.

In Model 2 of Table 4, we add measures of social and political orientations from the questionnaire (the items are taken from the World Value Survey). Consistently with previous studies (Glaeser et al., 2000), we do not find any significant relationship between the trust measured with the World Value Survey item and our experimental measure. We do find, instead, that the answer to the question "How much do you think is important to help the people nearby; to care for their well-being?" (Questionnaire Help) is moderately but significantly related to the trustor's decision in the Trust Game. We believe that this question is capturing some altruistic preferences and indeed, the results in Model 3 of Table 4 seem to support this intuition. Specifically, when we add both the questionnaire measures of social preferences and the incentive compatible measure of generosity, both the significance and the 
Table 4: Regressions on the determinants of trust and beliefs

\begin{tabular}{|c|c|c|c|c|c|c|}
\hline & $\begin{array}{c}\text { Trust } \\
\text { Model } 1 \\
\end{array}$ & $\begin{array}{c}\text { Trust } \\
\text { Model } 2 \\
\end{array}$ & $\begin{array}{c}\text { Trust } \\
\text { Model } 3\end{array}$ & $\begin{array}{c}\text { Beliefs } \\
\text { Model } 4 \\
\end{array}$ & $\begin{array}{c}\text { Beliefs } \\
\text { Model } 5\end{array}$ & $\begin{array}{c}\text { Beliefs } \\
\text { Model } 6\end{array}$ \\
\hline High SES (d) & $\begin{array}{r}0.439 \\
(0.396)\end{array}$ & $\begin{array}{r}0.589 \\
(0.381)\end{array}$ & $\begin{array}{r}0.334 \\
(0.402)\end{array}$ & $\begin{array}{r}0.019 \\
(0.031)\end{array}$ & $\begin{array}{r}0.058 \\
(0.035)\end{array}$ & $\begin{array}{r}0.020 \\
(0.030)\end{array}$ \\
\hline Hinterland (d) & $\begin{array}{r}0.060 \\
(0.439)\end{array}$ & $\begin{array}{r}0.594 \\
(0.410)\end{array}$ & $\begin{array}{r}0.076 \\
(0.443)\end{array}$ & $\begin{array}{r}0.032 \\
(0.033)\end{array}$ & $\begin{array}{r}0.057 \\
(0.038)\end{array}$ & $\begin{array}{r}0.037 \\
(0.033)\end{array}$ \\
\hline Opponent from High SES (d) & $\begin{array}{r}-0.226 \\
(0.393)\end{array}$ & $\begin{array}{r}-0.058 \\
(0.367)\end{array}$ & $\begin{array}{r}-0.204 \\
(0.397)\end{array}$ & $\begin{array}{r}0.012 \\
(0.030)\end{array}$ & $\begin{array}{r}0.000 \\
(0.035)\end{array}$ & $\begin{array}{r}0.006 \\
(0.029)\end{array}$ \\
\hline Opponent Hinterland (d) & $\begin{array}{r}0.303 \\
(0.406)\end{array}$ & $\begin{array}{r}0.113 \\
(0.390)\end{array}$ & $\begin{array}{r}0.328 \\
(0.425)\end{array}$ & $\begin{array}{r}-0.038 \\
(0.031)\end{array}$ & $\begin{array}{r}-0.028 \\
(0.036)\end{array}$ & $\begin{array}{l}-0.054 * \\
(0.031)\end{array}$ \\
\hline $\begin{array}{l}\text { Preferences and beliefs } \\
\text { Beliefs }\end{array}$ & $\begin{array}{l}6.390^{* * *} \\
(1.220)\end{array}$ & & $\begin{array}{c}6.438^{* * *} \\
(1.253)\end{array}$ & & & \\
\hline Generosity & $\begin{array}{l}4.746^{* * *} \\
(0.900)\end{array}$ & & $\begin{array}{l}4.518^{\text {**** }} \\
(0.931)\end{array}$ & $\begin{array}{r}0.083 \\
(0.063)\end{array}$ & & $\begin{array}{r}0.103 \\
(0.063)\end{array}$ \\
\hline Risk Attitude & $\begin{array}{r}1.476 \\
(1.049)\end{array}$ & & $\begin{array}{r}1.123 \\
(1.064)\end{array}$ & $\begin{array}{r}0.083 \\
(0.080)\end{array}$ & & $\begin{array}{r}0.091 \\
(0.079)\end{array}$ \\
\hline Impatience & $\begin{array}{r}-0.363 \\
(0.548)\end{array}$ & & $\begin{array}{r}-0.377 \\
(0.568)\end{array}$ & $\begin{array}{r}0.050 \\
(0.041)\end{array}$ & & $\begin{array}{c}0.068 * \\
(0.041)\end{array}$ \\
\hline Trustworthiness & & & & $\begin{array}{l}0.167^{* * *} \\
(0.026)\end{array}$ & & $\begin{array}{l}0.166^{* * *} \\
(0.026)\end{array}$ \\
\hline Questionnaire answers & & & & & & \\
\hline Questionnaire Help & & $\begin{array}{c}0.282^{* *} \\
(0.125)\end{array}$ & $\begin{array}{r}0.100 \\
(0.131)\end{array}$ & & $\begin{array}{c}0.023^{*} \\
(0.011)\end{array}$ & $\begin{array}{r}0.010 \\
(0.009)\end{array}$ \\
\hline Questionnaire Government & & $\begin{array}{r}-0.095 \\
(0.078)\end{array}$ & $\begin{array}{r}-0.078 \\
(0.081)\end{array}$ & & $\begin{array}{r}-0.008 \\
(0.007)\end{array}$ & $\begin{array}{r}-0.004 \\
(0.006)\end{array}$ \\
\hline Questionnaire Poverty & & $\begin{array}{r}0.142 \\
(0.093)\end{array}$ & $\begin{array}{r}0.147 \\
(0.099)\end{array}$ & & $\begin{array}{r}0.002 \\
(0.009)\end{array}$ & $\begin{array}{r}-0.008 \\
(0.007)\end{array}$ \\
\hline Questionnaire Trust & & $\begin{array}{r}0.187 \\
(0.318)\end{array}$ & $\begin{array}{r}0.016 \\
(0.349)\end{array}$ & & $\begin{array}{r}-0.015 \\
(0.030)\end{array}$ & $\begin{array}{r}-0.034 \\
(0.026)\end{array}$ \\
\hline Constant & & & & $\begin{array}{r}0.133 \\
(0.105)\end{array}$ & $\begin{array}{c}0.247^{*} \\
(0.128)\end{array}$ & $\begin{array}{r}0.127 \\
(0.119)\end{array}$ \\
\hline Controls & Yes & Yes & Yes & Yes & Yes & Yes \\
\hline N.obs. & 140 & 144 & 140 & 140 & 144 & 140 \\
\hline$R^{2}$ & 0.176 & 0.037 & 0.184 & -1.238 & -0.217 & -1.324 \\
\hline
\end{tabular}

Notes: Model 1-3: Ordered Logit regressions. Model 4-6: Tobit regressions. Symbols $* * *, * *$, and $*$ indicate significance at the $1 \%, 5 \%$ and $10 \%$ level, respectively. Dummy variables are indicated by the letter $d$. Controls include the following variables: Age of the participant in years; the dummy Female takes value 1 for females and 0 for males; the dummy Student takes value 1 if the participant is a student; the dummy Moved takes value 1 if a participant was born in an area different from the one he/she was living at the time of the experiment. Questionnaire Help is taken from the World Value Survey and it measures in a scale from 0 to 10 the answer to the question: "How much do you think is important to help the people nearby; to care for their well-being?". Questionnaire Government is taken from the World Value Survey and it measures in a scale from 0 to 10 the answer to the question: "How would you place your views on this scale?", where 0 corresponds to the answer "Government should take more responsibility to ensure that everyone is provided for" and 10 to the answer "People should take more responsibility to provide for themselves"; Questionnaire Poverty is taken from the World Value Survey and it measures in a scale from 0 to 10 the answer to the question: "In your opinion, why in this Country there are people living in poverty and in a state of need?", where 0 corresponds to the answer "Due to their laziness and lack of willpower" and 10 to the answer "Due to an unfair society." 
magnitude of Generosity and Questionnaire Help coefficients change due to some collinearity. ${ }^{15}$

Result 4. Beliefs about trustworthiness and generosity are the main drivers of trust. Moreover, most of the difference in trust across areas is explained by beliefs.

We find that the initial amount of trust is strongly correlated with the beliefs about trustworthiness but also with altruistic preferences, especially when experimentally elicited. Moreover, we find that much of the across-areas variation in the residents' level of trust is captured by the difference in the beliefs between High and Low SES residents. Given that we have shown that the strongest component explaining behavior in the Trust Game are beliefs, we now investigate what drives their formation.

Beliefs. In Models 4 to 6 of Table 4, we use a similar approach to the one we just described for trust behavior. This time the dependent variable are the beliefs about trustworthiness. As before, we add a first block of variables, including the preferences elicited in the experiment, and a second block with answers to questionnaire items. Based on the previous evidence (Butler et al., 2015), we want to test if there is a consensus effect in the belief formation. That is, when thinking about their opponents' level of trustworthiness, subjects might form their beliefs by putting themselves in the shoes of the other player but by reasoning with their own mind and values. If that is the case, subjects' beliefs on the other players' trustworthiness have to be correlated with their own trustworthiness. Model 4 in Table 4 shows indeed that in our sample there is a strong and positive correlation between trustworthiness and beliefs about others' trustworthiness. Social and political opinion - as measured in the questionnaire - have only weak predictive power in this case (Model 5). When including both preferences, and questionnaire items (Model 6), we still find strong support for a consensus effect.

All the above results on the determinants of trust hold true if we consider a linear specification or if we restrict the sample to those participants who did not move across areas (i.e., stayers). ${ }^{16}$

Result 5. There is a consensus effect in the beliefs formation: beliefs about trustworthiness are strongly associated with one's own level of trustworthiness.

\footnotetext{
${ }^{15}$ The pairwise correlation between our incentivized measure of generosity and Questionnaire Help is of 0.20 and significant at the $5 \%$ level.

${ }^{16}$ Results are available upon request from the authors.
} 


\section{Conclusions}

A recent strand of the literature has documented the existence of a strong link between socio-economic background and individual preferences among children (Bauer et al., 2014; Castillo et al., 2011; Deckers et al., 2015; Delaney and Doyle, 2012; Kosse et al., 2018) and adults (Gustavsson and Jordahl, 2008). Here we study whether such a link persists even in a highly homogeneous population of young adults: university students. Our subjects all have approximately the same age, they are all born in the same metropolitan area, and experienced a similar educational path. Yet, they come from districts characterized by a substantially different socio-economic environment. With a set of incentivized experiments, we investigate if these disparities across neighborhoods correlate with residents' preferences in strategic and non-strategic situations. In addition, we measure if subjects condition their behavior on the area of residence of their counterpart.

Our results indicate that participants living in an area characterized by a high socio-economic environment tend to trust more, as compared to those coming from less wealthy neighborhoods. The data suggest that this behavioral difference is, at least in part, driven by a difference in beliefs: subjects from the most affluent part of the city have more optimistic expectations on their counterpart's trustworthiness than those who live in the part of the city which is characterized by a lower socio-economic environment. We also find evidence that residents of wealthy neighborhoods are more inclined to reciprocate higher levels of trust, as compared to those living in the Low SES area. We interpret this as evidence of a "consensus" effect (Butler et al., 2015), that might be amplified in a more homogeneous environment (Sapienza et al., 2013). By contrast, no significant differences emerge in terms of generosity (Dictator Game), risk-attitudes, and time preferences, which are all elicited through tasks that do not imply any strategic interaction.

On the other hand, we do not find any systematic evidence of out-group or in-group discrimination. In particular, results from the Trust Game and the Dictator Game show that participants do not condition their beliefs and behavior on their counterpart's area of residence. This result is in line with Blanco and Guerra (2017) who run a Trust Game and a Dictator Game with college students with a high or low socio-economic status, in Colombia. While these findings do not necessarily generalize to the general public (see for instance Falk and Zehnder (2013)). In our case, the trustee is likely to be a university student, ${ }^{17}$ the trustor

\footnotetext{
${ }^{17}$ We did not provide any specific information on the individual characteristics of the opponent, but the questions subjects had to answer before starting to play would probably allow them to infer the nature of the
} 
might think that he is different from his lot, and more akin to other students than to the average resident in that area.

Our findings indicate that even in a highly selected sample, after almost twenty years of schooling and despite being exposed to daily interactions with peers from different backgrounds, the socio-economic status of the area of residence has a persistent effect on trust and trustworthiness. From a policy perspective, this suggests that in a world characterized by increasing economic inequality, it is important to focus also on differences in preferences that seem to be rooted in the individual experiences made in the earliest years of life.

\section{References}

Andreoni, J., N. Nikiforakis, and J. Stoop (2017). Are the Rich More Selfish than the Poor, or Do They Just Have More Money? A Natural Field Experiment. Working Paper 23229, National Bureau of Economic Research.

Ashraf, N., I. Bohnet, and N. Piankov (2006). Decomposing trust and trustworthiness. Experimental Economics 9(3), 193-208.

Bauer, M., J. Chytilová, and B. Pertold-Gebicka (2014). Parental background and otherregarding preferences in children. Experimental Economics 17(1), 24-46.

Bellettini, G., C. B. Ceroni, and C. Monfardini (2016). Neighborhood heterogeneity and electoral turnout. Electoral Studies 42, 146-156.

Berg, J., J. Dickhaut, and K. McCabe (1995). Trust, Reciprocity, and Social History. Games and Economic Behavior 10(1), 122-142.

Blanco, M. and J. A. Guerra (2017). To segregate, or to discriminate? That is the social identity question. Mimeo.

Butler, J. V., P. Giuliano, and L. Guiso (2015). Trust, Values, and False Consensus. International Economic Review 56(3), 889-915.

Castillo, M., P. J. Ferraro, J. L. Jordan, and R. Petrie (2011). The today and tomorrow of kids: Time preferences and educational outcomes of children. Journal of Public Economics 95(1112), 1377-1385.

subject pool. 
Chakravarty, S., M. A. Fonseca, S. Ghosh, and S. Marjit (2016). Religious fragmentation, social identity and cooperation: Evidence from an artefactual field experiment in India. Social Identity and Discrimination 90, 265-279.

Chen, D. L., M. Schonger, and C. Wickens (2016). oTreeAn open-source platform for laboratory, online, and field experiments. Journal of Behavioral and Experimental Finance 9, 88-97.

Chetty, R., N. Hendren, and L. F. Katz (2016). The effects of exposure to better neighborhoods on children: New evidence from the moving to opportunity experiment. The American Economic Review 106(4), 855-902.

Chuah, S. H., S. Gächter, R. Hoffmann, and J. H. Tan (2016). Religion, discrimination and trust across three cultures. Social Identity and Discrimination 90, 280-301.

Costa-Gomes, M. A. and G. Weizsäcker (2008). Stated Beliefs and Play in Normal-Form Games. Review of Economic Studies 75(3), 729-762.

Cox, J. C. (2004). How to identify trust and reciprocity. Games and Economic Behavior 46(2), 260-281.

Crosetto, P. and A. Filippin (2013). The bomb risk elicitation task. Journal of Risk and Uncertainty 47(1), 31-65.

Deckers, T., A. Falk, F. Kosse, and H. Schildberg-Hörisch (2015). How does socio-economic status shape a child's personality?

Delaney, L. and O. Doyle (2012). Socioeconomic differences in early childhood time preferences. Journal of Economic Psychology 33(1), 237-247.

Falk, A. and C. Zehnder (2013). A city-wide experiment on trust discrimination. Journal of Public Economics 100, 15-27.

Fershtman, C. and U. Gneezy (2001). Discrimination in a Segmented Society: An Experimental Approach. Quarterly Journal of Economics 116(1), 351-377.

Gächter, S. and E. Renner (2010). The effects of (incentivized) belief elicitation in public goods experiments. Experimental Economics 13(3), 364-377.

Gambetta, D. (1988). Can We Trust Trust? In D. Gambetta (Ed.), Trust: Making and Breaking Cooperative Relations. Basil Blackwell. 
Glaeser, E. L., D. I. Laibson, J. A. Scheinkman, and C. L. Soutter (2000). Measuring Trust. Quarterly Journal of Economics 115(3), 811-846.

Golsteyn, B. H., H. Grönqvist, and L. Lindahl (2014). Adolescent Time Preferences Predict Lifetime Outcomes. Economic Journal 124(580), 739-761.

Greiner, B. (2015). Subject pool recruitment procedures: organizing experiments with ORSEE. Journal of the Economic Science Association 1(1), 114-125.

Gustavsson, M. and H. Jordahl (2008). Inequality and trust in Sweden: Some inequalities are more harmful than others. Journal of Public Economics 92(1), 348-365.

Kahneman, D., J. L. Knetsch, and R. Thaler (1986). Fairness as a Constraint on Profit Seeking: Entitlements in the Market. American Economic Review 76(4), 728-741.

Koopmans, R. and S. Veit (2014). Ethnic diversity, trust, and the mediating role of positive and negative interethnic contact: A priming experiment. Social Science Research 47, 91-107.

Kosse, F., T. Deckers, P. R. Pinger, H. Schildberg-Hörisch, and A. Falk (2018). The Formation of Prosociality: Causal Evidence on the Role of Social Environment. Journal of Political Economy (forthcoming).

Lane, T. (2016). Discrimination in the laboratory: A meta-analysis of economics experiments. European Economic Review 90, 375-402.

McEvily, B., J. R. Radzevick, and R. A. Weber (2012). Whom do you distrust and how much does it cost? An experiment on the measurement of trust. Games and Economic Behavior 74(1), 285-298.

Mischel, W., Y. Shoda, and M. I. Rodriguez (1989). Delay of gratification in children. Science 244(4907), 933-938.

Moffitt, T. E., L. Arseneault, D. Belsky, N. Dickson, R. J. Hancox, H. Harrington, R. Houts, R. Poulton, B. W. Roberts, S. Ross, M. R. Sears, W. M. Thomson, and A. Caspi (2011). A gradient of childhood self-control predicts health, wealth, and public safety. Proceedings of the National Academy of Sciences 108(7), 2693-2698.

OECD (2011). Divided we stand: why inequality keeps rising. OECD Publisher.

Piff, P., M. Kraus, S. Ct, B. Cheng, and D. Keltner (2010). Having less, giving more: The influence of social class on prosocial behavior. Journal of Personality and Social Psychology 99(5), 771-784. 
Sapienza, P., A. Toldra-Simats, and L. Zingales (2013). Understanding Trust. The Economic Journal 123(573), 1313-1332.

Schechter, L. (2007). Traditional trust measurement and the risk confound: An experiment in rural Paraguay. Journal of Economic Behavior \& Organization 62(2), 272-292.

Sutter, M., M. G. Kocher, D. Glätzle-Rüetzler, and S. T. Trautmann (2013). Impatience and Uncertainty: Experimental Decisions Predict Adolescents' Field Behavior. American Economic Review 103(1), 510-531.

Weng, W. and F. Yang (2014). The impact of social identity on trust in China: experimental evidence from cross-group comparisons. Applied Economics 46(16), 1855-1860. 


\section{Appendices}

\section{Appendix A: Tables and Figures}

Table A1: Socio-demographic characteristics of the subject pool

\begin{tabular}{lcccc}
\hline \hline & \multicolumn{4}{c}{ Area of residence } \\
& \multicolumn{3}{c}{ at the time of the experiment } \\
& Low SES & High SES & Hinterland & Overall \\
\hline Demographics & & & & \\
$\quad$ Age (in years) & 24 & 24 & 23 & 24 \\
$\quad$ Females (\%) & 54 & 50 & 53 & 52 \\
Education & & & & \\
$\quad$ Ability (above average) (\%) & 43 & 58 & 53 & 53 \\
University student (\%) & 81 & 78 & 81 & 80 \\
$\quad$ STEM Major (\%) & 43 & 56 & 44 & 49 \\
Completed a bachelor degree (\%) & 46 & 42 & 33 & 40 \\
Residency & & & & \\
$\quad$ Moved (\%) & 22 & 30 & 19 & 24 \\
$\quad$ Live with parents (\%) & 78 & 69 & 88 & 77 \\
$\quad$ Friend in High SES (\%) & 30 & 45 & 14 & 32 \\
\hline N. observations & 37 & 64 & 43 & 144 \\
\hline
\end{tabular}

Notes: Ability takes value 1 if the participant states his/her High-school performance was above average; Stem takes value 1 if the major chosen in college is in Science, Engineering and Architecture or in Economics, Management and Statistics. Moved takes value 1 if a participant was born in an area different from the one he/she was living at the time of the experiment; Live with parents takes value 1 if the participant reported that he/she was living with their parents at the time of the experiment; Friend in High SES takes value 1 if the participant reported that the his/her best friend lives in a district of the High SES area. A series of Wilcoxon rank-sum tests (for age) and z-tests (for all other variables) fail to find any statistically significant difference for any pairwise comparison, with only one exception. The number of participants living with parents in the High SES and Hinterland is significantly different $(p=0.019)$. 
Table A2: In-group vs. out-group behavior

\begin{tabular}{lccc}
\hline \hline & $\begin{array}{c}\text { Same } \\
\text { area }\end{array}$ & $\begin{array}{c}\text { Different } \\
\text { area }\end{array}$ & $\begin{array}{c}\text { Wilcoxon rank-sum } \\
p \text {-value }\end{array}$ \\
\hline Trust Game & & & \\
$\quad$ Trust & 0.455 & 0.470 & 0.785 \\
$\quad$ Trustworthiness & 0.957 & 1.097 & 0.362 \\
$\quad$ Beliefs about trustworthiness & 0.309 & 0.323 & 0.726 \\
Dictator Game & & & \\
$\quad$ Generosity & 0.323 & 0.316 & 0.904 \\
N. of observations & 47 & 97 & 144 \\
\hline
\end{tabular}

Table A3: Regression on SES area and preferences (situations without strategic interaction)

\begin{tabular}{lccc}
\hline \hline & $\begin{array}{c}\text { Generosity } \\
\text { Model 1 }\end{array}$ & $\begin{array}{c}\text { Risk attitude } \\
\text { Model 2 }\end{array}$ & $\begin{array}{c}\text { Impatience } \\
\text { Model } 3\end{array}$ \\
\hline Area of residence of the decision maker & & \\
High SES (d) & 0.059 & -0.016 & 0.013 \\
& $(0.059)$ & $(0.032)$ & $(0.089)$ \\
Hinterland (d) & 0.073 & 0.002 & -0.135 \\
Area of residence of the counterpart & $(0.034)$ & $(0.098)$ \\
Opponent from High SES (d) & 0.030 & & \\
Opponent Hinterland (d) & $(0.058)$ & & \\
Constant & 0.023 & & \\
Controls & $(0.060)$ & & 0.480 \\
F-test High SES = Hinterland & 0.086 & $0.603 * * *$ & $(0.268)$ \\
F-test Opponent High SES $=$ & $0.180)$ & $(0.094)$ & Yes \\
Opponent Hinterland & 0.989 & 0.537 & 0.106 \\
N.obs. & 144 & & \\
$R^{2}$ & 0.085 & -0.027 & 0.038 \\
\hline
\end{tabular}

Notes: Results from Tobit regression; symbols ${ }^{* * *},{ }^{* *}$, and ${ }^{*}$ indicate significance at the $1 \%, 5 \%$ and $10 \%$ level, respectively. Dummy variables are indicated by the letter $d$. Controls include the following variables: Age of the participant in years; the dummy Female takes value 1 for females and 0 for males; the dummy Student takes value 1 if the participant is a student; the dummy Moved takes value 1 if a participant was born in an area different from the one he/she was living at the time of the experiment. 
Figure A1: Districts and areas of Bologna

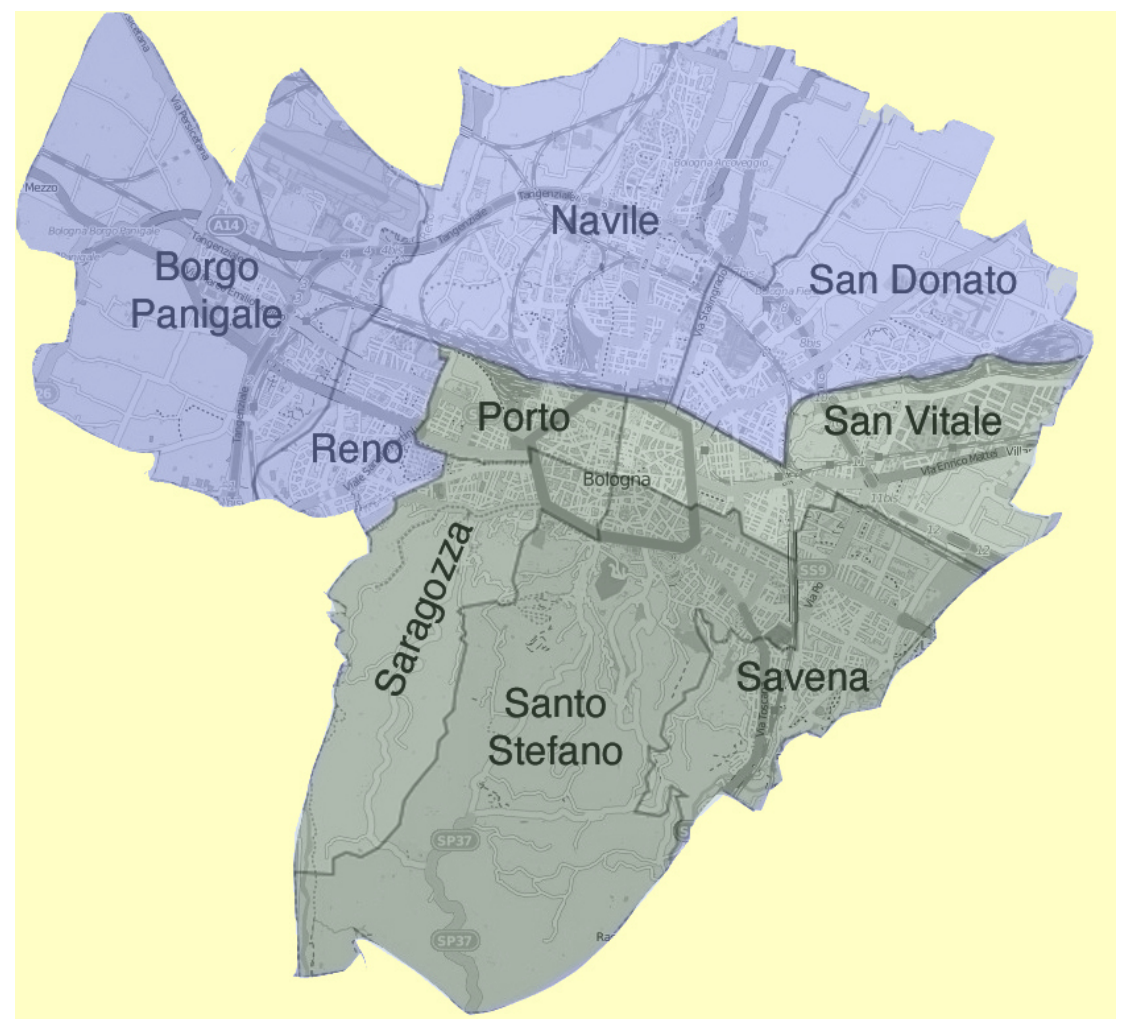


Figure A2: In-group and out-group trustworthiness, by SES area

\section{Low SES area}

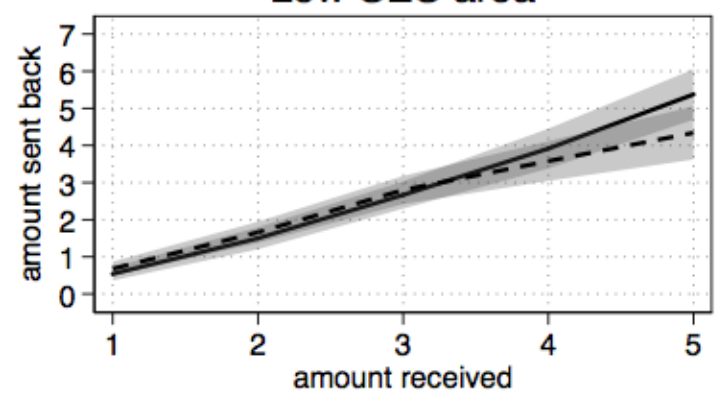

\section{Hinterland}

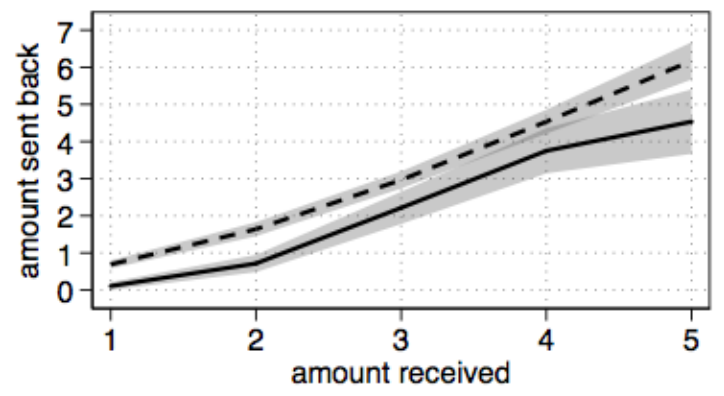

High SES area

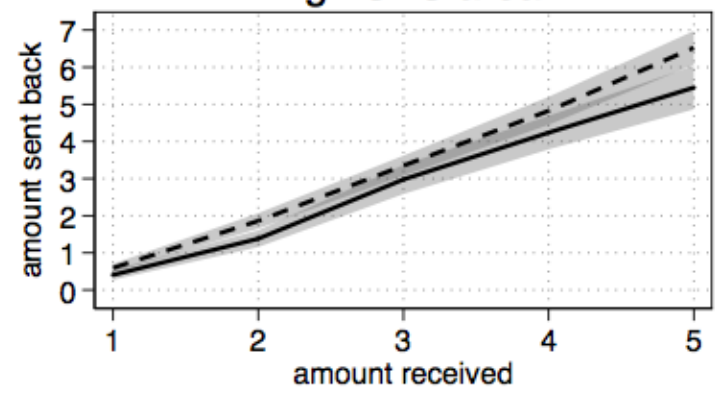

Overall

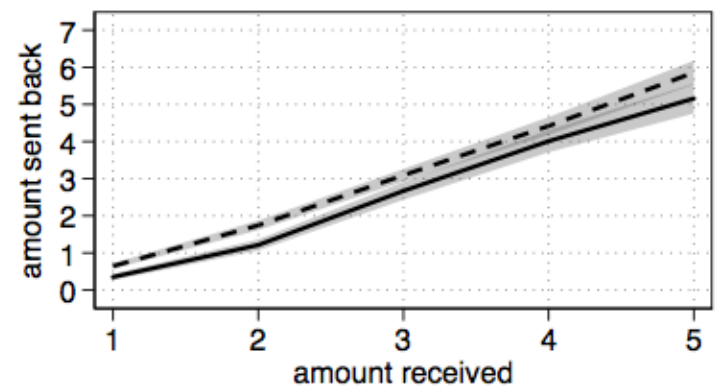

\section{In-group ----. Out-group}

Notes: The Figure displays the average amount of money returned by trustees, given the amount of money received, by trustee's and opponent's areas. In-group refers to the case in which the opponent is from the same area of the trustee. Out-group refers to the case where the trustee and the opponent are from different areas. 


\section{Appendix B: Experimental Instructions}

\section{Introduction}

Welcome! Thank you for participating in this study.

The study is made up of 6 tasks, which are going to be presented to you one after another. At the beginning of each task, we are going to give you specific instructions. The instructions are really simple and there is no right answer. At most 30 minutes will be required in order to complete all the 6 tasks. You can pause the task and resume it anytime until 24.00 of May 29, 2016.

Please, add this page to the "bookmarks" of your browser in order to access it again in case of log-out.

By completing all the tasks you could earn an amount of money usually between 0 and 30 Euro; this amount will depend on the decisions you take and on the ones taken by other participants in this study. Instructions of each task are going to give you further information about possible gains.

All decisions are going to be collected anonymously.

When you are ready to begin, click on "Next". 


\section{Task 1}

In this task you will have to answer to some questions about you and your daily habits.

Before you begin, we ask you to read the information sheet about the participation in the task.

Press the button "I declare to have read the information sheet".

1. Select the neighbourhood you live in. If you are not sure, check on this map.

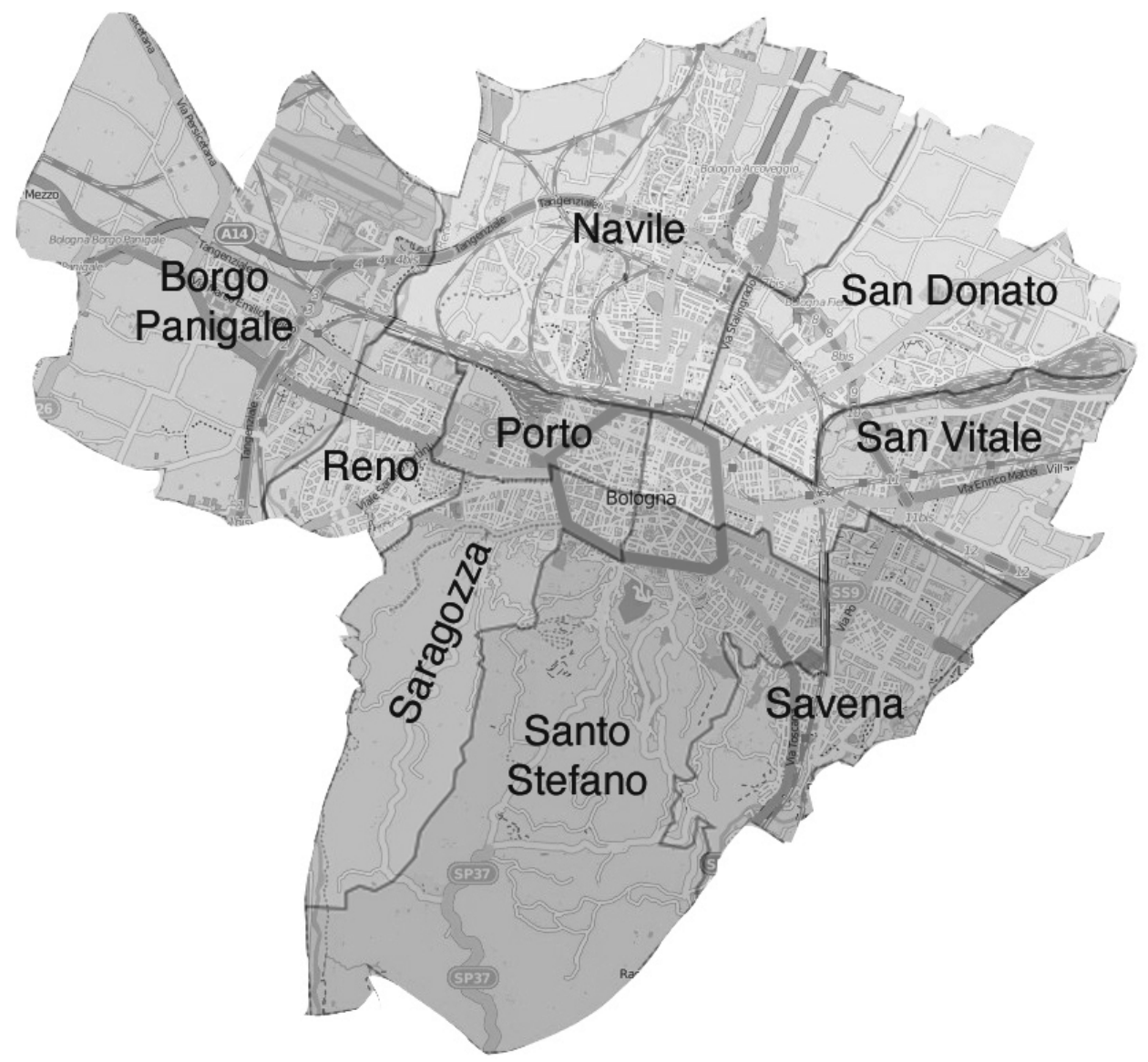

- Borgo Panigale

- Navile

- Porto

- Reno 
- San Donato

- Santo Stefano

- San Vitale

- Saragozza

- Savena

- Other

2. Who do you share your accommodation with?

- With my family (parents, grandparents, brothers and/or sisters, ...)

- With my partner

- With one or more friends

- With one or more flatmates

- With no one else

- Other

3. Which high school did you attend?

- Belluzzi-Fioravanti

- Copernico

- Fermi

- Galvani

- Manfredi-Tanari

- Mattei

- Minghetti

- Righi

- Sabin

- Salesiani

- Other

4. Which means of transport do you use for everyday movement? You can select more than one answer. 
- Bus

- Train

- Car

- Scooter

- Bike

- By foot

- Other

5. What do you do in your spare time?

You can select more than one answer.

- Individual sport (cycling, athletics, swimming, ...)

- Team sport (volleyball, football, basketball, ...)

- Other sports (tennis, ping pong, fencing, ...)

- Music

- Volunteer work

- Other 


\section{Task 2}

Other players have participated, or are about to do so, in this activity just like you. All answers are collected anonymously on our server.

For this task the interaction is going to be in pairs, which are going to be formed at the end of the study. Your answers are going to be matched to those of another player, born in the Bologna province and living in the green/yellow/blue zone (see map). The player you are matched with is randomly selected among the participants to this study.

You are not going to know anything else about the player you are matched and the same is true about her/him. Your payoffs may instead depend on the choices of the player you are matched with and vice-versa.

Please click on the "Next" button to proceed with the instructions.

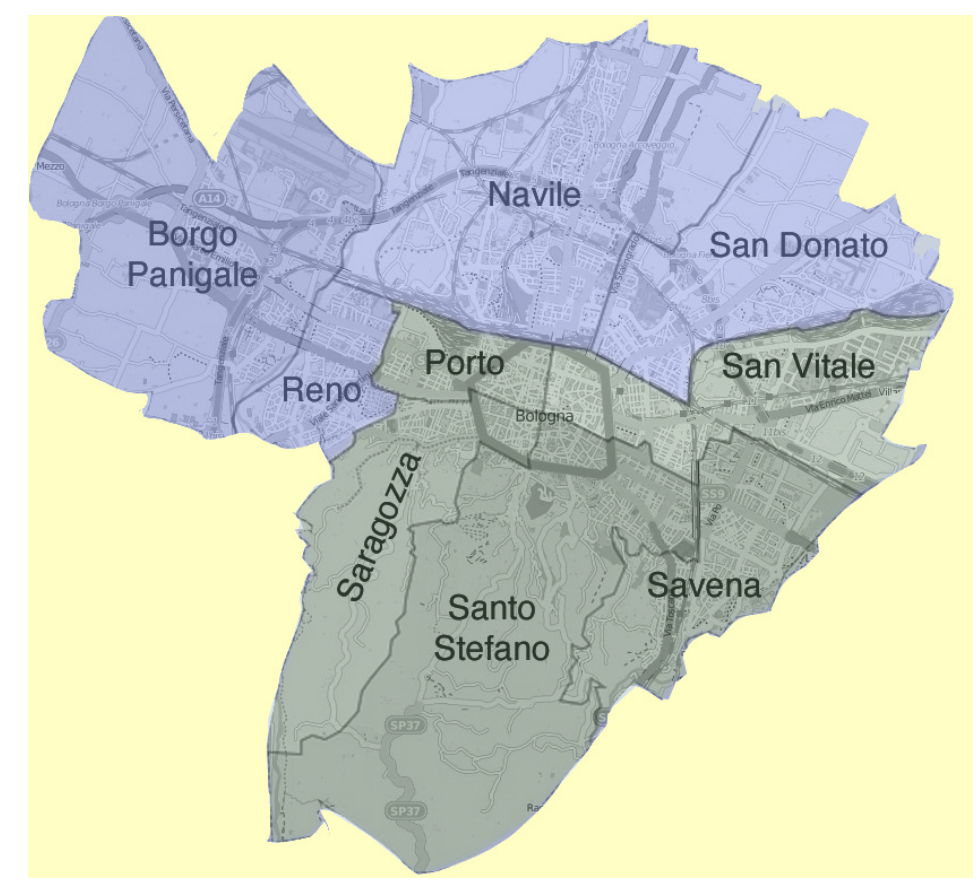

In each pair there is a player $\mathrm{A}$ and a Player $\mathrm{B}$.

Player A receives 5 1-Euro coins and has to decide how many of them to keep for him/herself and how many to put in a box to give to player B. 
If player A decides to keep for him/herself all the 5 coins, the game ends (A keeps 5 Euro and $\mathrm{B}$ does not receive anything).

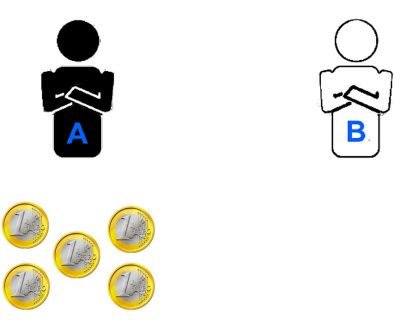

If player A decides to put some coins into the box, these are going to be tripled and passed to player B.

For instance, if A keeps 4 coins for him/herself and puts one into the box, A will have 4 Euros while the Euro in the box is tripled. Player B therefore receives 3 Euro.

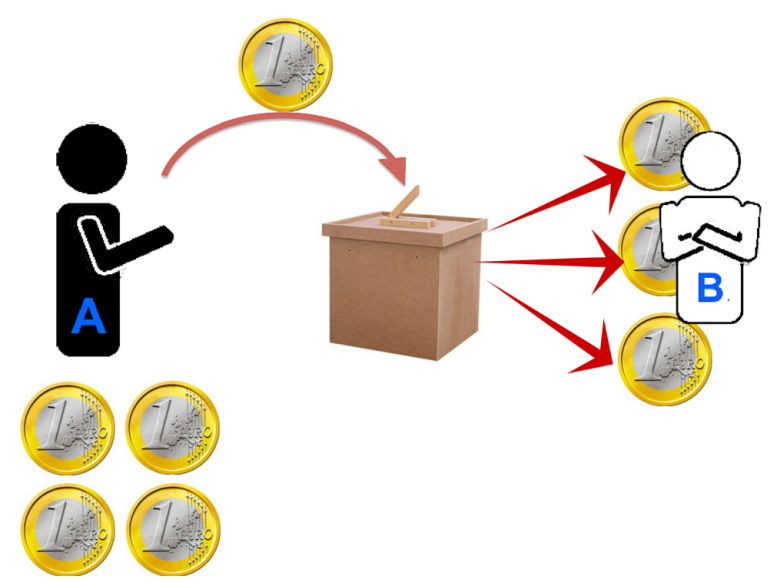

Proceed with the instructions by clicking the "Next" button.

In case:

- A keeps 4 Euro and puts 1 in the box, B receives 3 Euro (1 Euro x 3).

- A keeps 3 Euro and puts 2 in the box, B receives 6 Euro (2 Euro x 3).

- A keeps 2 Euro and puts 3 in the box, B receives 9 Euro (3 Euro x 3). 
- A keeps 1 Euro and puts 4 in the box, B receives 12 Euro (4 Euro x 3).

- A keeps 0 Euro and puts 5 in the box, B receives 15 Euro (5 Euro x 3).

In each of these cases, B is going to decide how much to keep for him/herself and how much to give to $\mathrm{A}$.

The payoff of player B is equal to the amount he/she decides to keep for him/herself.

The payoff of $\mathrm{A}$ is equal to the amount he/she kept for him/herself of the starting 5 Euros plus the amount he/she is given by player B.

Roles are going to be assigned only at the end of the study. Therefore we ask you to take a decision for both roles.

Please click on the "Next" button to proceed.

\section{Control questions}

Before we start, we ask you to answer some questions in order to check that the instructions are completely clear to you.

1. If A decides to keep all the 5 Euro, how much does B gain?

2. If $\mathrm{A}$ decides to put all the 5 Euro in the box to pass to $\mathrm{B}$ and $\mathrm{B}$ decides to split equally the amount received:

- How many Euro does B receive to split between him/her and A? (please recall received Euro are tripled)

- How many Euro does B gain?

- How many Euro does A gain? (Please recall A decided to put all the 5 Euro in the box)

\section{Answers to control questions 1 and 2}

1. If A decides to keep all 5 Euro, how much does B gain? Answer: Player B is going to have 0 Euro. 
Explanation: Player A passed 0 Euro to player B.

2. If A decides to put all the 5 Euro in the box to pass to B and B decides to split equally the amount received:

- How many Euro does B receive? Answer: Player B receives 15 Euro.

Explanation: The amount received is tripled.

- How many Euro does B gain? Answer: Player B gains 7,50 Euro.

Explanation: B decides to split equally the amount received.

- How many Euro does A gain? Answer: Player A gains 7,50 Euro.

Explanation: A passed 5 Euro and received back 7,50 Euro. Then his/her gain is: $5-5+7,50=7,50$ Euro.

Please click on "Next" button to proceed.

3. If $\mathrm{A}$ decides to put 2 Euro in the box to pass to B and B decides to give back 1 Euro to A and keep the rest for him/herself:

- How many Euro does B receive to split between A and him/herself? (please recall money put in the box is tripled)

- How many Euro does B gain?

- How many Euro does A gain? (A decided to keep 3 Euro and put 2 in the box)

\section{Answer to control question 3}

3. If $\mathrm{A}$ decides to put 2 Euro in the box to pass to $\mathrm{B}$ and $\mathrm{B}$ decides to give back 1 Euro to $\mathrm{A}$ and keep the rest for him/herself:

- How many Euro does B receive to split between A and him/herself? (please recall money put in the box is tripled) Solution: Player B receives 6 Euro.

Explanation: The amount received is tripled. 
- How many Euro does B gain? Solution: Player B gains 5 Euro.

Explanation: B decides to pass 1 Euro to A, then he/she gains: $6-1=5$ Euro.

- How many Euro does A gain? Solution: Player A gains 4 Euro.

Explanation: A passed 2 Euro e received back 1 Euro.Then his/her gain is: 5 - 2 $+1=4$ Euro.

Please click on the "Next" button to proceed.

\section{Decision I (role A)}

If you are assigned role A, what would you like to do with the 5 Euro?

- I would keep 5 Euro and put 0 Euro in the box to pass to B.

- I would keep 4 Euro and put 1 Euro in the box to pass to B.

- I would keep 3 Euro and put 2 Euro in the box to pass to B.

- I would keep 2 Euro and put 3 Euro in the box to pass to B.

- I would keep 1 Euro and put 4 Euro in the box to pass to B.

- I would keep 0 Euro and put 5 Euro in the box to pass to B.

\section{Decision II (role B)}

If you are assigned role A, what decision would you take for each of these options?

\section{Final question}

How much do you think that B players living in the green/yellow/blue see map would pass to $\mathrm{A}$, in percentage? 


\begin{tabular}{l|l}
$\begin{array}{l}\text { If A player you are matched with } \\
\text { decides to put in the box: }\end{array}$ & As player B, \\
\hline 1 Euro & $\begin{array}{l}\text { I give back to A ....... Euro } \\
\text { (number between } 0 \text { and } 3 \text { Euro, in increments of } 50 \text { Euro } \\
\text { cents) }\end{array}$ \\
\hline 2 Euro & $\begin{array}{l}\text { I give back to A ....... Euro } \\
\text { (number between } 0 \text { and } 6 \text { Euro, in increments of } 50 \text { Euro } \\
\text { cents) }\end{array}$ \\
\hline 3 Euro & $\begin{array}{l}\text { I give back to A ....... Euro } \\
\text { (number between } 0 \text { and } 9 \text { Euro, in increments of } 50 \text { Euro } \\
\text { cents) }\end{array}$ \\
\hline 5 Euro & $\begin{array}{l}\text { I give back to A ....... Euro } \\
\text { (number between } 0 \text { and } 12 \text { Euro, in increments of } 50 \text { Euro } \\
\text { cents) }\end{array}$ \\
\hline 5 Euro & $\begin{array}{l}\text { I give back to A ....... Euro } \\
\text { (number between } 0 \text { and } 15 \text { Euro, in increments of } 50 \text { Euro } \\
\text { cents) }\end{array}$ \\
\hline
\end{tabular}

- $0 \%$ of what received by $\mathrm{A}$.

- $10 \%$ of what received by A.

- $20 \%$ of what received by A.

- $30 \%$ of what received by A.

- $40 \%$ of what received by A.

- $50 \%$ of what received by A.

- $60 \%$ of what received by A.

- $70 \%$ of what received by A.

- $80 \%$ of what received by A.

- $90 \%$ of what received by A.

- $100 \%$ of what received by A. 


\section{Task 3}

Also for this activity, your answers and those of all other players are going to be collected anonymously on our server. Interaction is going to take place in pairs which are going to be formed at the end of the study. Your answers are going to be matched to those of another player, born in the Bologna province and living in the green/yellow/blue zone (see map). The player your are matched with is randomly selected among the participant to this study and he/she is not necessarily the one you were matched to in Task 2. You are not going to know anything else about the player you are matched with and the same is true for him/her. Your payoff may depend on the choices of the player matched to you and vice-versa.

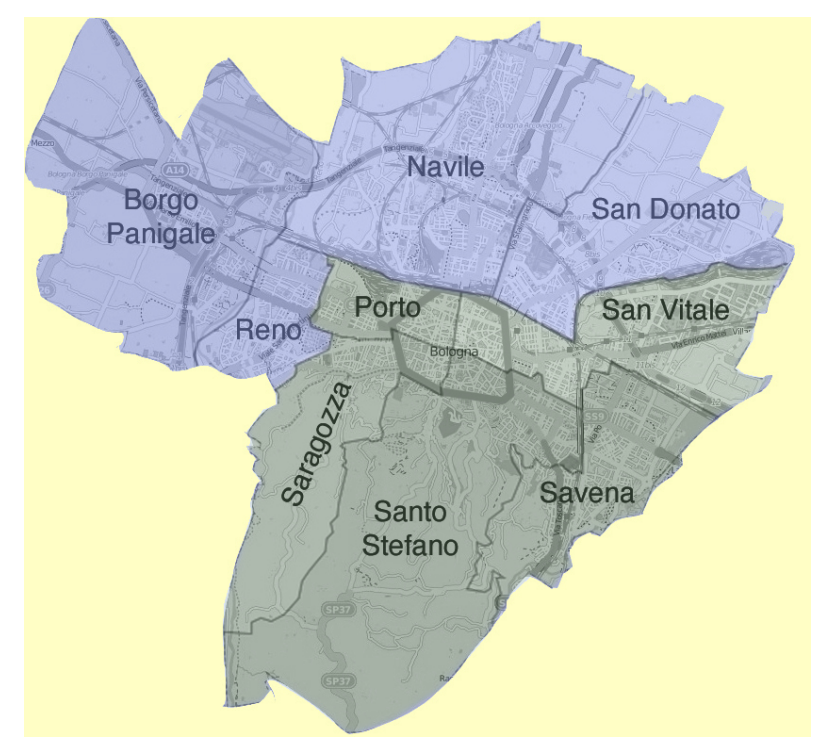

As in task 2, in the pair there are a player A and a player B. A receives 10 1-Euro coins and has to decide how many of these coins to keep for him/herself and how many to give to player B. B does not have to take any decision.

Roles are going to be assigned only at the end of the study. If you are assigned role A, your payoff will depend on your decision. If you are assigned role B, your payoff will depend on the decision of the player you are matched with. 


\section{Decision I (role A)}

If you are given the role of player A, how would you split the 10 1-Euro coins? Please take a decision and click on the "Next" button.

\begin{tabular}{|l|c|c|c|}
\hline & FOR ME & FOR B & Total \\
\hline Number of coins & & & 10 \\
\hline
\end{tabular}




\section{Task 4}

In this task we are going to ask you to take 10 decisions. For each decision, you will have to choose if you prefer to receive:

- 100 Euro Tuesday June 7, 2016 (Option A);

- a sum greater than 100 Euro Wednesday September 7, 2016 (Option B).

You will have to take a decision for each row of the table, stating if you prefer Option A or Option B. For instance, for the first row of the table you have to state whether you prefer to receive 100 Euro on June 7, 2016 (Option A) or 103 Euro on September 7, 2016 (Option B). For the second row, you have to state whether you prefer to receive 100 Euro on June 7, 2016 or 106 Euro on September 7, 2016 and so on.

Please note that Option A is the same for all 10 decisions (rows), while Option B varies (more precisely, the amount of money increases of 3 Euro in each row).

\begin{tabular}{|c|c|c|c|c|}
\hline Row $\mathrm{n}$. & Option A & A & B & Option B \\
\hline 1 & 100 Euro on June 7 & $\square$ & $\square$ & 103 Euro on September 7 \\
\hline 2 & 100 Euro on June 7 & $\square$ & $\square$ & 106 Euro on September 7 \\
\hline 3 & 100 Euro on June 7 & $\square$ & $\square$ & 109 Euro on September 7 \\
\hline 4 & 100 Euro on June 7 & $\square$ & $\square$ & 112 Euro on September 7 \\
\hline 5 & 100 Euro on June 7 & $\square$ & $\square$ & 115 Euro on September 7 \\
\hline 6 & 100 Euro on June 7 & $\square$ & $\square$ & 118 Euro on September 7 \\
\hline 7 & 100 Euro on June 7 & $\square$ & $\square$ & 121 Euro on September 7 \\
\hline 8 & 100 Euro on June 7 & $\square$ & $\square$ & 124 Euro on September 7 \\
\hline 9 & 100 Euro on June 7 & $\square$ & $\square$ & 127 Euro on September 7 \\
\hline 10 & 100 Euro on June 7 & $\square$ & $\square$ & 130 Euro on September 7 \\
\hline
\end{tabular}

When the study is over, one out of 20 participants is going to be randomly selected for the payment of this task. If you are selected, you are going to be paid for just one of the 10 choices you made. The choice determining your payoff will also be randomly selected.

For this task all payments, whichever the date chosen, are going to be done by bank transfer. The transfer is going to be done in the chosen date. If you are selected, you are going to receive detailed information about the transfer via e-mail. 


\section{Control questions}

Please answer the following question. We reported below the table of decisions for your convenience.

1. In case you are selected at the end of the study for the payment and the row selected in number 3 , when are you going to be paid if you chose option A?

- on June 7

- on September 7

2. In case you are selected at the end of the study for the payment and the row selected in number 7 , how much will you earn if you chose option B?

\section{Answers to control questions}

1. In case you are selected at the end of the study for the payment and the row selected in number 3, when are you going to be paid if you chose option A? Answer: Payment will be on June 7.

Explanation: If you choose option A you will be always paid on June 7 .

2. In case you are selected at the end of the study for the payment and the row selected is number 7, how much will you earn if you chose option B? Answer: The value of option B on September 7 is 121 Euro.

Explanation: To know the payoff you have to look at the seventh row of the table reported in correspondence of option B.

\section{Your decisions}

Please take a decision for each row of the table, then click on "Next" to proceed. 


\begin{tabular}{|c|c|c|c|c|}
\hline Row $n$. & Option A & $\mathbf{A}$ & B & Option B \\
\hline 1 & 100 Euro on June 7 & $\square$ & $\square$ & 103 Euro on September 7 \\
\hline 2 & 100 Euro on June 7 & $\square$ & $\square$ & 106 Euro on September 7 \\
\hline 3 & 100 Euro on June 7 & $\square$ & $\square$ & 109 Euro on September 7 \\
\hline 4 & 100 Euro on June 7 & $\square$ & $\square$ & 112 Euro on September 7 \\
\hline 5 & 100 Euro on June 7 & $\square$ & $\square$ & 115 Euro on September 7 \\
\hline 6 & 100 Euro on June 7 & $\square$ & $\square$ & 118 Euro on September 7 \\
\hline 7 & 100 Euro on June 7 & $\square$ & $\square$ & 121 Euro on September 7 \\
\hline 8 & 100 Euro on June 7 & $\square$ & $\square$ & 124 Euro on September 7 \\
\hline 9 & 100 Euro on June 7 & $\square$ & $\square$ & 127 Euro on September 7 \\
\hline 10 & 100 Euro on June 7 & $\square$ & $\square$ & 130 Euro on September 7 \\
\hline
\end{tabular}




\section{Task 5}

In this task you can earn between 0 and 12 Euro, according to the choices you will make.

On the screen you will see a table with 25 numbered cells. For each activated cell, your payoff for this task increases by 50 cents of Euro. Every 2 seconds a cell is activated, starting from the top left corner. Once activated, a cell is coloured in red and your payoff are updated on the screen.

These gains are only potential: behind one of the cells, in fact, there is a time bomb that could destroy all your payoff. You are not told where the bomb is, you only know it could be in any cell with equal probability. Even in case you activated the cell with the bomb, you are going to be informed about that only at the end of this task.

Your task is to decide when you want to stop (i.e. when you do not want any other cell to be activated). You can press the STOP button at any moment: this will entail that no other cell is activated. Once you push the STOP button, you are going to be shown where the bomb is. If you activated the cell in which the bomb is, for this activity your payoff is 0 . If the bomb is in a cell you did not activate, your payoff for this task is equal to what you gained since you pressed the START button until you pressed the STOP button.

For your convenience, these instructions are going to remain visible, at the bottom of the page, even in next screens.

\section{Control questions}

Before we start, we ask you to answer some questions in order to check that the instructions are completely clear to you.

1. Suppose you have pressed the STOP button 12 seconds after the start of the activity. This means cells from 1 to 6 have been activated.

- How much do you earn if the bomb was in cell 21 ?

- How much do you earn if the bomb was in cell 4 ?

2. Suppose you have pressed the STOP button 37 seconds after the start of the activity. This means cells from 1 to 18 have been activated. 
- How much do you earn if the bomb was in cell 21 ?

- How much do you earn if the bomb was in cell 4 ?

\section{Answers to control questions}

1. Suppose you have pressed the STOP button 12 seconds after the start of the activity. This means cells from 1 to 6 have been activated.

- How much do you earn if the bomb was in cell 21? Answer: The payoff is going to be 3 Euro.

Explanation: Given the bomb was in a cell after those activated, your gains are not nullified and are going to be equal to 3 Euro, 0.50 Euro cents times 6 cells.

- How much do you earn if the bomb was in cell 4? Answer: The payoff is going to be 0 Euro.

Explanation: Given the bomb was under an activated cell, your payoff is 0 Euro.

2. Suppose you have pressed the STOP button 37 seconds after the start of the activity. This means cells from 1 to 18 have been activated.

- How much do you earn if the bomb was in cell 21? Answer: The payoff is going to be 9 Euro.

Explanation: Given that the bomb was in a cell after those activated, your gains are not nullified and are going to be equal to 9 Euro, 0.50 Euro cents times 18 cells.

- How much do you earn if the bomb was in cell 4? Answer: The payoff is going to be 0 Euro.

Explanation: Given the bomb was under an activated cell, your payoff is 0 Euro. 


\section{Your decision}

On the screen you can see the table with 25 numbered cells. Now all the cells are white. When you are ready to begin, press START. Since when you press STARS, every 2 seconds a cell is activated starting from the top left corner. Once a cell is coloured in red, you payoff is updated.

When you want to stop, i.e. when you do not want any more cells to be coloured, press STOP.

\section{Clicca su Start per cominciare.}

START

Clicca su Stop per terminare il processo.

STOP

\begin{tabular}{|c|c|c|c|c|}
\hline 1 & 2 & 3 & 4 & 5 \\
\hline 6 & 7 & 8 & 9 & 10 \\
\hline 11 & 12 & 13 & 14 & 15 \\
\hline 16 & 17 & 18 & 19 & 20 \\
\hline 21 & 22 & 23 & 24 & 25 \\
\hline
\end{tabular}

\section{Outcome of task 5}

You pressed "STOP" after colouring: .... cells

The bomb was in cell number: ...

Then you earned: ... 


\section{Task 6}

In this task you will have to answer to some questions about you and your daily habits. The answers you will give are not going to affect in any way your payoff. All information provided is going to be registered anonymously and treated confidentially.

Press "Next" as you are ready to start.

1. Age (in years)

2. Gender

- $\mathrm{M}$

- $\mathrm{F}$

3. Italian Nationality

- Yes

- $\mathrm{No}_{\mathrm{O}}$

4. Select the neighbourhood your family lived in when you were born. If you are not sure, check on this map.

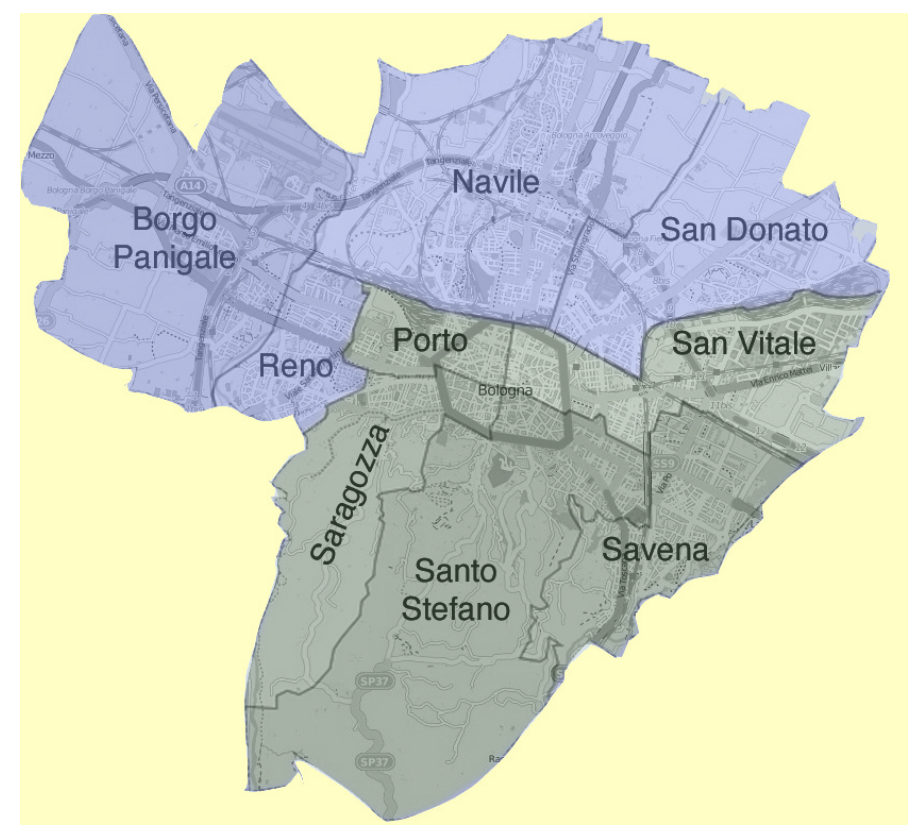


- Borgo Panigale

- Navile

- Porto

- Reno

- San Donato

- Santo Stefano

- San Vitale

- Saragozza

- Savena

- Other

5. What is your profession? You can select more than one answer.

- Student

- Self-employed worker

- Salaried worker

- Unemployed

- Other

6. In what of the following courses are you enrolled? (if you abandoned your studies or if you graduated, please select the course in which you where enrolled or in which you graduated)

- Agriculture and Veterinary Medicine

- Economics, Management and Statistics

- Pharmacy, Biotechnology and Sports Science

- Law

- Engineering and Architecture

- Arts, Humanities and Cultural Heritage

- Foreign Languages and Literatures, Interpreting and Translation

- Medicine and Surgery

- Psychology and Education Science

- Natural Science 
- Political Science

- I have never attended University courses

7. What is your highest degree?

- Primary school certificate

- Middle school certificate

- High school certificate (liceo, istituto tecnico, istituto professionale, ecc.)

- Bachelor degree;

- Master of Arts degree (Laurea vecchio ordinamento, Laurea specialistica or magistrale, Laurea a ciclo unico);

- Master of research or post-graduate specialisation;

- Ph.D;

8. In general, would you say most people can be trusted or you can never be too cautious in dealing with others?

- most people can be trusted

- you can never be too cautious

9. In general, you are a person willing to take risk or you try to avoid to take risks? Please, indicate your answer in a scale from 1 to 10, where 1 means you "do not want to take risks" e 10 means that "you are willing to take risks".

\begin{tabular}{|rccccccccccl|}
\hline I do not want & $\bigcirc$ & $\bigcirc$ & $\bigcirc$ & $\bigcirc$ & $\bigcirc$ & $\bigcirc$ & $\bigcirc$ & $\bigcirc$ & $\bigcirc$ & $\bigcirc$ & I am willing to \\
to take risks & 1 & 2 & 3 & 4 & 5 & 6 & 7 & 8 & 9 & 10 & take risks \\
\hline
\end{tabular}

10. In general, to what extent to you think it is important to help others, to care of their welfare? Please, indicate your answer in a scale from 1 to 10 , where 1 means "totally unimportant" and 10 means "totally important".

\begin{tabular}{|rccccccccccc|}
\hline totally unimportant & $\bigcirc$ & $\bigcirc$ & $\bigcirc$ & $\bigcirc$ & $\bigcirc$ & $\bigcirc$ & $\bigcirc$ & $\bigcirc$ & $\bigcirc$ & $\bigcirc$ & totally \\
unimportant & 1 & 2 & 3 & 4 & 5 & 6 & 7 & 8 & 9 & 10 & important \\
\hline
\end{tabular}

11. Where would you locate yourself on a scale from 1 to 10 , where 1 means that you agree completely with the statement on the left and 10 means you completely agree with the statement 
on the right? If your point of view is between the two, you can select an intermediate answer.

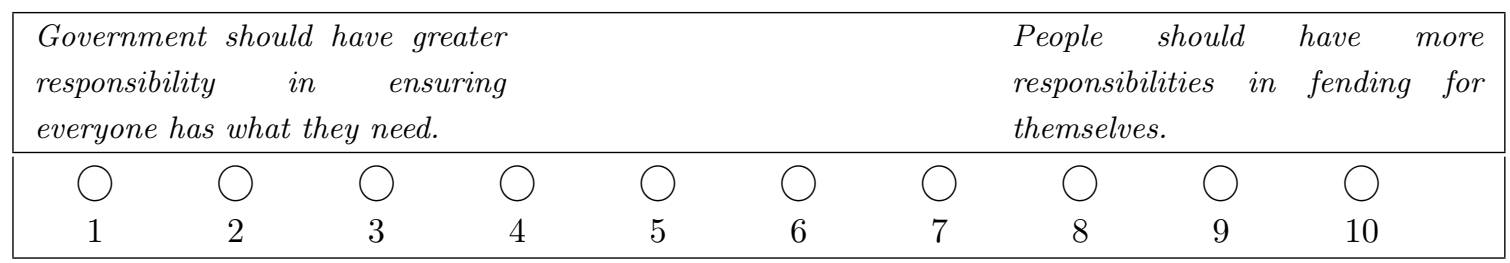

12. In your opinion, why in this Country there are people living in poverty and in a state of need? Please indicate your position on a scale from 1 to 10, where 1 means that you agree completely with the statement on the left and 10 means you completely agree with the statement on the right. If your point of view is between the two, you can select an intermediate answer.

\begin{tabular}{|c|cccccccc|}
\hline $\begin{array}{l}\text { Due to their laziness and lack of } \\
\text { willpower. }\end{array}$ \\
\hline 0
\end{tabular}

Now we are going to make you some questions about your best friend.

1. How did you get to know each other?

- At school

- At the University

- On the workplace

- Doing sport

- Doing volunteer work

- We were neighbours

- $\mathrm{He} / \mathrm{she}$ was friend of friends

- Other

2. Did he/she attend the same high school as you?

- Yes

- No

3. Were you in the same class at high school? 
- Yes

- No

4. In which zone of the city your best friend currently lives?

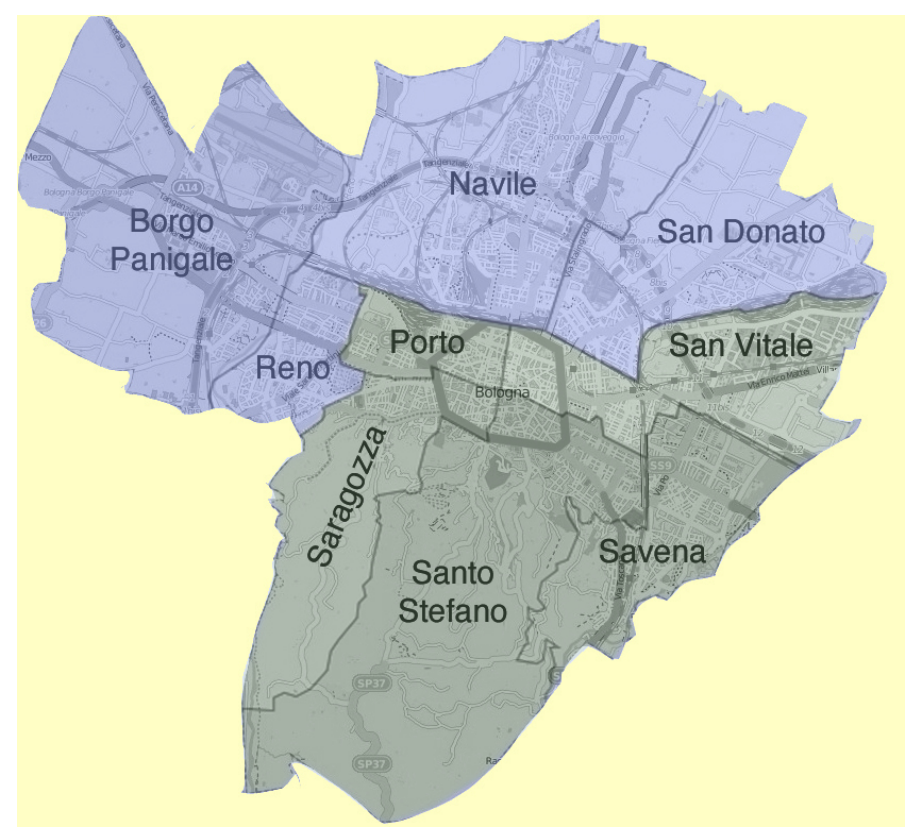

- Green zone

- Yellow zone

- Blue zone

- Other/I don't know

5. If compared to your high school classmates, your school performance was:

- Well above the average

- Above the average

- Average

- Below the average

- Well below the average

- I did not attend high school 


\section{Instructions and procedures for payment}

Your participation to this study is now concluded. Thank you for your cooperation!

No later than May 30, 2016 you are going to receive an e-mail with all the information about the payment and a link to see the outcome of all the tasks you just carried out. 


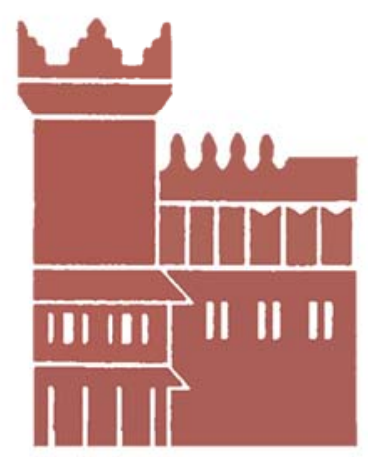

Alma Mater Studiorum - Università di Bologna DEPARTMENT OF ECONOMICS

Strada Maggiore 45

40125 Bologna - Italy

Tel. +39051 2092604

Fax +390512092664

http://www.dse.unibo.it 